\title{
Deep Eutectic Solvents as Unconventional Media for Multicomponent Reactions
}

\author{
Luiz S. Longo Jr. ${ }^{* a}$ and Marcus V. Craveiro ${ }^{b}$
${ }^{a}$ Departamento de Ciências Farmacêuticas, Instituto de Ciências Ambientais, Químicas e Farmacêuticas, Universidade Federal de São Paulo, Rua Prof Artur Riedel, 275, 09972-270 Diadema-SP, Brazil \\ ${ }^{b}$ Departamento de Química, Instituto de Ciências Ambientais, Químicas e Farmacêuticas, \\ Universidade Federal de São Paulo, Rua Prof Artur Riedel, 275, 09972-270 Diadema-SP, Brazil
}

\begin{abstract}
Regarding all the green aspects of sustainable chemical transformations, eco-friendly processes along with economic development, environmental protection as well as natural resources preservation are mandatory. The use of unconventional media for organic transformations has been part of the quest for new eco-friendly process. As new alternative media for volatile organic solvents, deep eutectic solvents (DES) can be defined as the eutectic mixtures formed of two or more phase-immiscible components, which furnish a new homogeneous liquid phase with lower freezing point than those observed for individual counterparts. They found applications in several different fields, such as solvent/catalyst for organic transformations, biotransformations, and polymerization reactions, metal and biomass processing applications, and separation technologies. This review describes the recent studies on the use of deep eutectic mixtures as solvent and/or catalyst for multicomponent reactions in the synthesis of complex organic compounds.
\end{abstract}

Keywords: deep eutectic solvent, multicomponent reaction, Green Chemistry, solvent selection, catalysis

\section{Introduction}

Over the last decades, the principles of Green Chemistry have been successfully embraced by the scientific community and now the awareness of environmental issues regarding chemical processes is considered as mandatory. Several contributions on the Green Chemistry issue can be found in the literature, covering different aspects of this topic. ${ }^{1-5}$ Noteworthy, Poliakoff and Licence ${ }^{6}$ addressed some questions that must be made when thinking of sustainable technology. "Why is chemical manufacture becoming unsustainable?"; it is their starting point. Our dependence on the petrochemical transformation industry has been increased over the last century as our lifestyle changed and demanded more complex products, such as new sophisticated materials (i.e., plastics, polymers, nanomaterials, etc.), fine chemicals, new drugs, etc. In this scenario, chemists and chemical engineers are expected to develop safe, sustainable and eco-friendly processes to attend all social demands as well as economic development, whilst providing environmental protection and preservation of the natural resources for future generations.

*e-mail: luiz.longo@unifesp.br
Regarding all green aspects of sustainable chemical transformations, such as atom economy, catalysis and energy efficiency, the reaction media has a central role. According to Constable et al., ${ }^{7}$ the solvent of the reaction accounts up to $80 \%$ of total material mass in active pharmaceutical ingredient (API) manufacture process. It is not surprising that some big pharmaceutical companies such as Pfizer, ${ }^{8}$ GSK, ${ }^{9}$ and Sanofi ${ }^{10}$ have recently developed solvent selection guides for the chemical processes in drug synthesis.

The reaction solvent is responsible for the modification of reactant, catalyst and/or product reactivity, for mass and heat transference phenomena, as well as the stabilization of transition states. In addition, solvents are also employed in extraction, washing and purification steps, either by recrystallization or chromatography. Therefore, the solvent has a huge impact in the reaction green metrics as it is used in large quantity in many steps throughout the process.

Common volatile organic compounds (VOCs) used as solvents are mainly composed of low molecular weight petrochemical derivatives and alcohols, which show many intrinsic drawbacks such as volatility, high flammability, toxicity and, in many cases, non-biodegradability. To overcome the disadvantages of conventional organic 
solvents, many alternative solvents have appeared over the past years, including ionic liquids, supercritical fluids (carbon dioxide and water), perfluorinated compounds, glycerol and other biomass-derived solvents, among others. However, many of these compounds impose several drawbacks regarding the large-scale use, mainly related to thermal and chemical stability, substrate/catalyst/product solubility, cost, sophisticated equipment need, and/or life-cycle assessment. ${ }^{11}$

Ionic liquids (ILs) are composed entirely of mobile ions, i.e., an organic cation (mainly imidazolium, pyrrolidinium, pyridinium, ammonium or phosphonium) and usually a halide anion (typically $\mathrm{Cl}^{-}$or $\mathrm{Br}^{-}$) or a weakly basic non-coordinating anion such as $\left[\mathrm{PF}_{6}\right]^{-},\left[\mathrm{BF}_{4}\right]^{-}$or $\left[\mathrm{NTf}_{2}\right]^{-.12}$ These low temperature molten salts are often referred to as "designer solvents", once adjustable physical or chemical properties may arise from the thousands of possible combinations of anions and cations. Ionic liquids have low vapor pressure and high boiling point, reducing loss to the environment and qualifying them to be recycled. However, the green credentials of this class of alternative solvents have been often questioned in the recent literature as their syntheses involve laborious and hazardous procedures and their toxicity profile is not fully understood. ${ }^{13,14}$

In 2003, Abbott et al. ${ }^{15}$ described a new type of solvent composed of choline chloride and different amides, such as urea, thiourea, benzamide and acetamide. The term "deep eutectic solvent" (DES) was then coined to describe the eutectic mixture formed of two or more phase-immiscible solid components which, upon stirring at a precise temperature, furnishes a new homogeneous liquid phase with lower freezing point, compared to those observed for individual counterparts. For the whole set of possible molar combinations of components, the eutectic point (EP) is defined as the minimum melting temperature observed at a specific molar ratio of $\mathrm{A}$ and $\mathrm{B}$.

As the interest in new green solvents spreads over the scientific community, the deep eutectic solvents have emerged as promising solvents for a wide range of different applications, ${ }^{16-19}$ including alternative solvents and/or catalysts for organic transformations in general, ${ }^{20-22}$ metal-catalyzed organic reactions, ${ }^{23}$ biotransformations, ${ }^{24,25}$ polymerization reactions, ${ }^{26}$ metal processing applications (metal electrodeposition and electropolishing), ${ }^{27,28}$ biomass processing, ${ }^{29}$ biodiesel synthesis, ${ }^{30}$ and separation processes..$^{31-33}$ The synthesis, properties and applications of deep eutectic mixtures were comprehensively reviewed by Zhang et al..$^{34}$ in 2012 and by Smith et al. ${ }^{35}$ in 2014.

Multicomponent reactions (MCRs) are defined as organic transformations involving three or more starting materials combining together in a single step to afford a product in which all atoms of the starting materials (or at least most of them) are incorporated into its structure. ${ }^{36}$ They are highly atom-efficient reactions with environmental friendly procedures, as only a catalytic amount of simple inorganic acids or bases is often required. Another important feature of such multiple-bond-forming transformations is the high degree of molecular complexity and diversity that can be achieved in a single step. The first MCR was discovered in 1850 by Strecker ${ }^{37,38}$ for the synthesis of $\alpha$-aminonitriles starting from carbonyl compounds (aldehyde or ketone), amines and cyanide ion; upon hydrolysis, the $\alpha$-aminonitriles thus obtained can be easily convert into the corresponding $\alpha$-amino acids. Further classical MCRs include those based on the chemistry of isocyanides (Passerini, ${ }^{39} \mathrm{Ugi}^{40,41}$ and Groebke-Blackburn-Bienaymé ${ }^{42}$ reactions) as well as the widely known and useful Mannich, ${ }^{43}$ Biginelli, ${ }^{44}$ and Hantzsch reactions ${ }^{45}$ among many others. Several aspects of MCRs and their applications in Organic Synthesis are extensively reviewed elsewhere. ${ }^{46-55}$

So far, the use of deep eutectic solvents in multicomponent reactions has not been fully and critically reviewed, despite the fact it was mentioned as part of some general review on the topic DES. ${ }^{21,22,56}$ Therefore, in this contribution we focus on the published studies in which deep eutectic mixtures are used as both solvent and/or catalyst in multicomponent reactions based on nucleophilic addition to imines or enamines, Knoevenagel condensation, nucleophilic attack of isocyanides to carbonyl compounds and related processes.

\section{Structure and Properties of DES}

Typically, deep eutectic mixtures are composed of nonsymmetric cations with low melting points (i.e., low lattice energy) and a metallic salt or a natural-derived compound as hydrogen-bond donor (HBD). Nonsymmetric tetrasubstituted ammonium salts are the most common type of cationic component, being choline chloride the most used salt because it is very cheap and easily accessible through different suppliers. The interaction that may arise from the combination of choline chloride and natural-derived hydrogen-bond donors, such as urea, ethylene glycol or oxalic acid, usually involves a charge delocalization effect which occurs via hydrogen bonds formed between the chloride ion and the hydrogen atoms from the HBD (Figure 1, exemplified for choline chloride/urea 1:2). The unusual solvent properties of DES are strongly influenced by those hydrogen bond interactions.

Up to now, many combinations of cationic salts and metallic salts or hydrogen-bond donors have been 
<smiles>C[Si](C)(CCO)NCNC(=O)NN</smiles>

Figure 1. Hydrogen-bond interactions proposed for choline chloride/urea (1:2) eutectic mixture.

described in the literature. Figure 2 shows the most common compounds used in the preparation of deep eutectic mixtures.

Deep eutectic solvents can be classified according to the components used in their preparation..$^{57}$ The most common and studied class of DES is that formed of quaternary ammonium salts, including 1,3-dialkylimidazolium and 1-alkylpyridinium cations, and anhydrous metal halides (type I). Some examples are the well-known chlorozincate $^{57-60}$ and chlorostannate ${ }^{61}$ eutectic mixtures as well as the melts formed with aluminium, ${ }^{62}$ iron, ${ }^{56,63}$ gallium, ${ }^{64}$ and indium salts. ${ }^{65}$ For example, a eutectic mixture of choline chloride $/ \mathrm{ZnCl}_{2}$ is obtained in a molar ratio of $1: 2$, respectively (freezing point ca. $24{ }^{\circ} \mathrm{C}$ ). Due to the anhydrous nature of the metallic salt, this type of DES requires more sophisticated handling apparatus once moisture can be an issue, depending on the application.

The use of hydrated metal halides $\left(\mathrm{MCl}_{3} \cdot \mathrm{xH}_{2} \mathrm{O}\right)$ is also possible, giving rise to the second class of DES. Eutectic mixtures of quaternary ammonium salts and hydrated metal halides (type II) are easier to handle and often cheaper than type I DES. In addition, they are air and moisture resistant in nature, more prompted to be used in industrial scale. Pioneering work of Abbott et al.$^{66}$ demonstrated the

Halide salts<smiles>C[N+](C)(C)CCO</smiles>

choline chloride (ChCl)<smiles>CCO[Ga]O[Si](CC)(CC)CCO</smiles><smiles>C[N+](C)(C)CCCl</smiles>

$\mathrm{ClChCl}$

$\mathrm{Et}_{2}(\mathrm{EtOH}) \mathrm{ACl}$<smiles>C[N+](C)(C)O</smiles><smiles></smiles><smiles>CC[N+](Br)(CC)CC</smiles>

$\mathrm{AcChCl}$<smiles>CCNCCN</smiles>

$\mathrm{E} \mathrm{NH}_{3} \mathrm{Cl}$<smiles>C[N+]([O-])(CCO)Cc1ccccc1</smiles>

$\mathrm{N}$-benzyl-2-hydroxy- $\mathrm{N}, \mathrm{N}-$ dimethylammonium

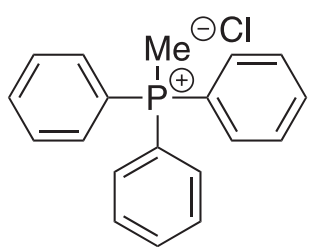

$\mathrm{MeP}(\mathrm{Ph})_{3} \mathrm{Br}$

\section{Hydrogen-bond donors}
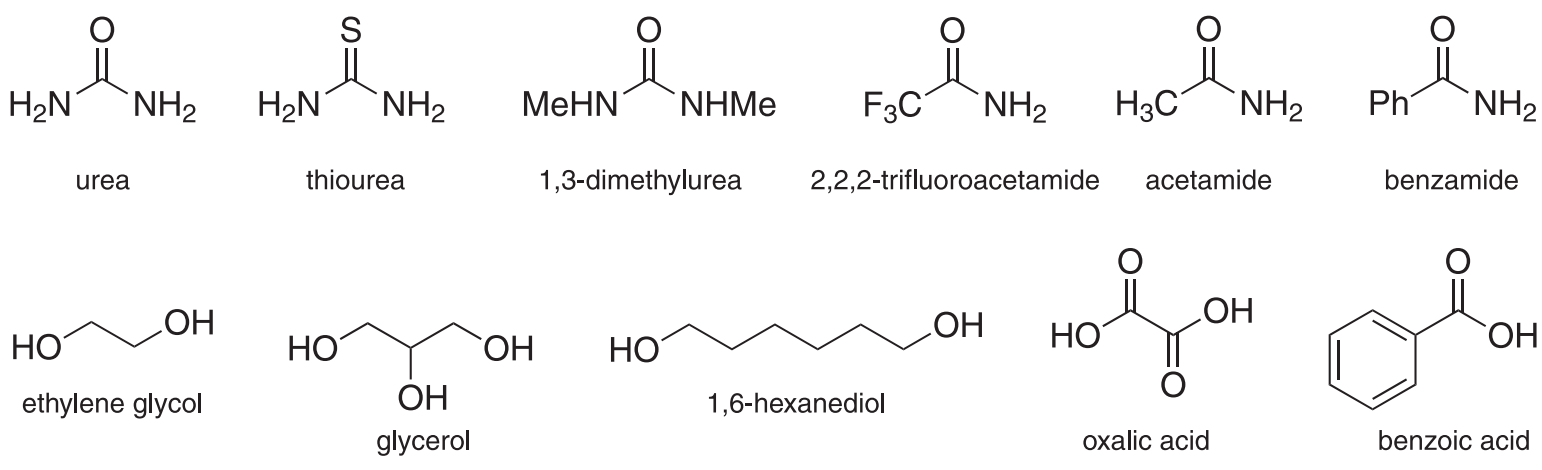<smiles>OCCCCCCO</smiles><smiles>O=C(O)C(=O)O</smiles>

oxalic acid<smiles>O=C(O)c1ccccc1</smiles><smiles>O=C(O)CC(O)(CC(=O)O)C(=O)O</smiles><smiles>O=C(O)CC(=O)O</smiles><smiles>O=C(O)CCC(=O)O</smiles>

succinic acid<smiles>O=C(O)[C@H](O)[C@@H](O)C(=O)O</smiles>

$L-(+)$-tartaric acid<smiles>CC(O)C(=O)O</smiles>

lactic acid

Figure 2. Common halide salts and hydrogen-bond donors (HBD) employed in the preparation of deep eutectic mixtures. 
physical properties of the dark green viscous liquid formed upon stirring of choline chloride/ $\mathrm{CrCl}_{3} \cdot 6 \mathrm{H}_{2} \mathrm{O}$ mixture (1:2; freezing point ca. $14{ }^{\circ} \mathrm{C}$ ). Recently, this eutectic mixture has been studied as catalyst for the esterification reaction of formic and acetic acid. ${ }^{67}$

Type III deep eutectic mixtures are composed of ammonium quaternary cations with neutral organic hydrogen-bond donors bearing functional groups such as $-\mathrm{CO}_{2} \mathrm{H},-\mathrm{CO}_{2} \mathrm{NH}_{2},-\mathrm{NH}_{2},-\mathrm{NHR}$ and $-\mathrm{OH}$. From the plethora of possibilities, urea is the most common one, giving rise to a eutectic mixture with choline chloride in a 1:2 molar ratio, respectively (freezing point ca. $12{ }^{\circ} \mathrm{C}$ ).$^{15}$ This type of DES has some advantages compared to the metal-based analogues, including low cost, easy preparation and relatively high water resistance. In addition, many of them are composed of natural biomass-derived organic HBD, which make them often seen as biodegradable and non-toxic. ${ }^{68-70}$

More recently, a fourth type of DES was described (type IV), which is composed of metal chloride salts with hydrogen-bond donors (without organic quaternary ammonium cations). Abbott et al. ${ }^{57}$ have found that $\mathrm{ZnCl}_{2}$ forms eutectic mixtures with different HBD such as urea, acetamide, ethylene glycol and 1,6-hexanediol.

There are many possibilities for combination of components in binary or ternary eutectic mixtures within the four types of DES described so far. In general, deep eutectic solvents have freezing points $<150{ }^{\circ} \mathrm{C}$ (many of them are indeed liquids at room temperature), are denser than water and exhibit high viscosities (typically $>100 \mathrm{cP}$ ). As they are intend to be used as solvents for organic reactions, a careful analysis of such properties is needed. Table 1 displays some important physico-chemical properties of the most common DES. For further information, the reader is encouraged to access data compiled in the excellent review contributions on this topic, recently published by Smith et al. ${ }^{35}$ and Zhang et al. ${ }^{34}$

\section{DES as Solvent and/or Catalyst in Multi- component Reactions}

\subsection{MCR based on nucleophilic addition to imines or enamines}

Biginelli reaction is one of the most important MCR to prepare 3,4-dihydropyrimidin-2-ones, a class of promising and important biologically active compounds. ${ }^{44,71}$ In 2011, Gore et al. ${ }^{72}$ reported the first study of the Biginelli reaction using type III DES, which plays a triple role as solvent, catalyst and also reactant. The authors found that a 3:7 mixture of L-(+)-tartaric acid/dimethylurea (DMU) can catalyze the reaction of different aldehydes with 1,3-dicarbonyl compounds in mild conditions, leading to $\mathrm{N}, \mathrm{N}$-dimethyl-3,4-dihydropyrimidin-2-ones (1) in good to excellent yields. Selected examples are shown in Scheme 1.

Later, Azizi et $a l .{ }^{73}$ studied the Biginelli reaction catalyzed by $\mathrm{ChCl} / \mathrm{SnCl}_{2}$ (1:2) as deep eutectic reaction medium and Lewis acid catalyst.

Quinazolines are also an important class of nitrogenbased heterocyclic compounds with broad spectrum of

Table 1. Summary of relevant physicochemical data for common deep eutectic solvents (DES) ${ }^{\mathrm{a}}$

\begin{tabular}{|c|c|c|c|c|}
\hline DES & $\mathrm{T}_{\mathrm{m}} /{ }^{\circ} \mathrm{C}$ & Density $(\rho)^{\mathrm{b}} /\left(\mathrm{g} \mathrm{cm}^{-1}\right)$ & Viscosity / cP & Conductivity $(\kappa) /\left(\mathrm{mS} \mathrm{cm}^{-1}\right)$ \\
\hline $\mathrm{ChCl}$ /urea $(1: 2)$ & 12 & 1.25 & $750\left(25^{\circ} \mathrm{C}\right)$ & $0.199\left(40^{\circ} \mathrm{C}\right)$ \\
\hline $\mathrm{ChCl} / \mathrm{CF}_{3} \mathrm{CONH}_{2}(1: 2)$ & $-45^{c}$ & 1.342 & $77\left(40^{\circ} \mathrm{C}\right)$ & $0.286\left(40^{\circ} \mathrm{C}\right)$ \\
\hline $\mathrm{ChCl} /$ ethylene glycol (1:2) & -66 & 1.12 & $37\left(25^{\circ} \mathrm{C}\right)$ & $7.61\left(20^{\circ} \mathrm{C}\right)$ \\
\hline $\mathrm{ChCl} /$ glycerol (1:2) & -40 & 1.18 & $376\left(20^{\circ} \mathrm{C}\right)$ & $1.05\left(20^{\circ} \mathrm{C}\right)$ \\
\hline $\mathrm{ChCl} / 1$,4-butanediol (1:2) & -32 & 1.06 & $140\left(20^{\circ} \mathrm{C}\right)$ & $1.64\left(40^{\circ} \mathrm{C}\right)$ \\
\hline $\mathrm{ChCl} /$ malonic acid $(1: 2)$ & 10 & 1.25 & $1124\left(25^{\circ} \mathrm{C}\right)$ & - \\
\hline $\mathrm{ChCl} /$ tartaric acid (1:2) & 47 & $1.27\left(30^{\circ} \mathrm{C}\right)$ & $66441\left(30^{\circ} \mathrm{C}\right)$ & $0.014\left(30^{\circ} \mathrm{C}\right)$ \\
\hline $\mathrm{ChCl} /$ glucose $(1: 2)$ & 14 & $1.21\left(85^{\circ} \mathrm{C}\right)$ & $8045.1\left(25^{\circ} \mathrm{C}\right)$ & - \\
\hline $\mathrm{ChCl} /$ imidazole (3:7) & 56 & - & $15\left(70^{\circ} \mathrm{C}\right)$ & $12\left(60^{\circ} \mathrm{C}\right)$ \\
\hline $\mathrm{ChCl} / \mathrm{ZnCl}_{2}(1: 2)$ & 24 & - & $85000\left(25^{\circ} \mathrm{C}\right)$ & $0.06\left(42^{\circ} \mathrm{C}\right)$ \\
\hline $\mathrm{ZnCl}_{2}$ /urea (1:3.5) & 9 & 1.63 & $11340\left(25^{\circ} \mathrm{C}\right)$ & $0.18\left(42{ }^{\circ} \mathrm{C}\right)$ \\
\hline $\mathrm{ZnCl}_{2} / \mathrm{CH}_{3} \mathrm{CONH}_{2}(1: 4)$ & -16 & 1.36 & - & - \\
\hline $\mathrm{ZnCl}_{2} /$ ethylene glycol (1:4) & -30 & 1.45 & - & - \\
\hline $\mathrm{ZnCl}_{2} / 1,6$-hexanediol (1:3) & -23 & 1.38 & - & - \\
\hline
\end{tabular}

${ }^{\mathrm{a}}$ For more details, see references 34 and 35 ; bdensity values measured at $25^{\circ} \mathrm{C}$, unless otherwise stated; cfreezing point obtained for a mixture of $\mathrm{ChCl} /$ $\mathrm{CF}_{3} \mathrm{CONH}_{2}$ in a 1:2.5 molar ratio. 
<smiles>[R]C(=O)CC([R])=O</smiles>

25 examples (70-99\%) $\mathrm{R}_{1}=\mathrm{Me}, \mathrm{Ph}$

$\mathrm{R}_{2}=\mathrm{Me}, \mathrm{OMe}, \mathrm{OEt}$, allyl<smiles>[X]c1ccc(CO)cc1</smiles>

$\mathrm{X}=\mathrm{H}, 4-\mathrm{NO}_{2}, 4-\mathrm{Cl}, 4-\mathrm{Br}, 4-\mathrm{OMe}$

Scheme 1. Biginelli reaction in L-(+)-tartaric acid/dimethylurea (3:7).

biological properties such as antitumor, ${ }^{74-76}$ antioxidant, ${ }^{77,78}$ anti-inflammatory, ${ }^{79,80}$ and antiviral, ${ }^{81}$ among many others.

Catalyst free synthesis of quinazoline derivatives was achieved by employing low melting point sugar-urea mixtures. ${ }^{82}$ The authors screened several different binary and ternary systems and found that a mixture composed of maltose, $\mathrm{DMU}$ and $\mathrm{NH}_{4} \mathrm{Cl}$ in a ratio of 5:4:1, respectively, was the best reaction media. Under relatively mild conditions, 2-aminoaryl ketones, aldehydes and ammonium acetate furnished a series of forty five quinazolines (2) in good to excellent yields (Table 2; selected examples).

Similarly, 2,3-dihydroquinazolin-4(1H)-ones (3) were obtained by using choline chloride/malonic acid (1:1) as catalyst. ${ }^{83}$ The reaction of isatoic anhydride, aromatic aldehydes and anilines, using $20 \%(\mathrm{v} / \mathrm{v})$ of $\mathrm{ChCl} /$ malonic acid $(1: 1)$ in methanol at $65^{\circ} \mathrm{C}$, led to the desired products 3 in $80-95 \%$ yield (Scheme 2). The catalyst could be recovered after each reaction cycle by evaporation of the methanol and water (after the isolation process of the products), thus allowing it to be reused for five consecutive cycles without loss of activity. The authors suggested that the acidic catalyst is actually participating in three steps within the proposed reaction mechanism: (i) the nucleophilic attack of the aniline to the carbonyl group of the anhydride, (ii) the formation of the imine intermediate $\mathbf{4}$, and (iii) the cyclization step of $\mathbf{4}$, which led to the 2,3-dihydroquinazolin-4(1H)-one core (Scheme 3).

The Kabachnik-Fields reaction using Lewis acidic eutectic mixtures for the preparation of $\alpha$-aminophosphonates was investigated by Disale et al. ${ }^{84}$ in 2012. Reactions involving aromatic aldehydes, diethyl
Table 2. Synthesis of quinazolines (2) using maltose/DMU/ $\mathrm{NH}_{4} \mathrm{Cl}$ (5:4:1) as deep eutectic solvent ${ }^{\mathrm{a}}$

\begin{tabular}{|c|c|c|c|c|c|}
\hline & & $\mathrm{NH}$ & $\mathrm{H}_{4} \mathrm{OAc}$ & 2 & $\mathrm{R}_{1}$ \\
\hline entry & $\mathrm{X}$ & $\mathrm{R}_{1}$ & $\mathrm{R}_{2}$ & time / min & Yield $^{\mathrm{b}} / \%$ \\
\hline 1 & $\mathrm{Cl}$ & $\mathrm{C}_{6} \mathrm{H}_{5}$ & $\mathrm{C}_{6} \mathrm{H}_{5}$ & 180 & 86 \\
\hline 2 & $\mathrm{Cl}$ & $\mathrm{C}_{6} \mathrm{H}_{5}$ & $3,4-(\mathrm{OMe})_{2} \mathrm{C}_{6} \mathrm{H}_{3}$ & 90 & 93 \\
\hline 3 & $\mathrm{Cl}$ & $\mathrm{C}_{6} \mathrm{H}_{5}$ & 4-pyridyl & 200 & 87 \\
\hline 4 & $\mathrm{Cl}$ & $\mathrm{C}_{6} \mathrm{H}_{5}$ & 2-thienyl & 170 & 91 \\
\hline 8 & $\mathrm{Cl}$ & 2-Cl- $\mathrm{C}_{6} \mathrm{H}_{4}$ & $3-\mathrm{CF}_{3}-\mathrm{C}_{6} \mathrm{H}_{4}$ & 240 & 90 \\
\hline 9 & $\mathrm{Cl}$ & 2-Cl- $\mathrm{C}_{6} \mathrm{H}_{4}$ & 2-thienyl & 300 & 86 \\
\hline 7 & $\mathrm{NO}_{2}$ & $\mathrm{C}_{6} \mathrm{H}_{5}$ & $3-\mathrm{Cl}-\mathrm{C}_{6} \mathrm{H}_{4}$ & 250 & 80 \\
\hline 5 & $\mathrm{H}$ & $\mathrm{C}_{6} \mathrm{H}_{5}$ & $\mathrm{C}_{6} \mathrm{H}_{5}$ & 200 & 87 \\
\hline 6 & $\mathrm{H}$ & $\mathrm{C}_{6} \mathrm{H}_{5}$ & $4-\mathrm{NO}_{2}-\mathrm{C}_{6} \mathrm{H}_{4}$ & 150 & 93 \\
\hline 10 & $\mathrm{H}$ & $\mathrm{Me}$ & 3-pyridyl & 200 & 88 \\
\hline
\end{tabular}

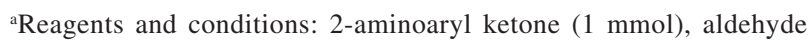
( $1 \mathrm{mmol})$, ammonium acetate $(1 \mathrm{mmol})$ were stirred in maltose/DMU/ $\mathrm{NH}_{4} \mathrm{Cl}$ (ratio 5:4:1, respectively) $(1.5 \mathrm{~g})$ at $90^{\circ} \mathrm{C}$, whilst air was bubbled into the reaction medium; bisolated yields. DMU: dimethylurea.

phosphite and aniline were completed within short periods of time at room temperature when $\mathrm{ChCl} / \mathrm{ZnCl}_{2}(1: 2)$ was used as catalyst (Scheme 4). The authors proposed a mechanism where $\mathrm{ZnCl}_{2}$ participates as Lewis acid catalyst in the formation of an imine intermediate. Based on earlier speciation studies of $\mathrm{ChCl} / \mathrm{ZnCl}_{2}$ mixtures, ${ }^{58}$ the authors also suggested that $\left[\mathrm{ZnCl}_{3}\right]^{-},\left[\mathrm{Zn}_{2} \mathrm{Cl}_{5}\right]^{-}$, and $\left[\mathrm{Zn}_{3} \mathrm{Cl}_{7}\right]^{-}$ion clusters presented within the ionic liquid may also act as Lewis bases abstracting a proton from diethyl phosphite. This leads to a nucleophilic phosphite specie that attacks the imine to furnish the desired $\alpha$-aminophosphonates (5), upon further protonation (Scheme 5).

The participation of chlorozincate clusters as Lewis acid catalyst was also claimed to explain the mechanism of the one-pot multicomponent synthesis of 4-[(3-indolyl) (aryl)methyl]- $N, N$-dimethylanilines (6) catalyzed by $\mathrm{ChCl} / \mathrm{ZnCl}_{2}(1: 3) .{ }^{85}$ Accordingly, the existence of chloride ion in these clusters may lower the Lewis acidity in comparison to the free $\mathrm{ZnCl}_{2}$, and the authors overcame this effect by increasing the molar ratio of zinc chloride to choline chloride. Furthermore, acidic chlorozincate clusters of general formula $\left[\mathrm{Zn}_{\mathrm{x}} \mathrm{Cl}_{2 x+1}\right]^{-}$were assigned to participate in the reaction mechanism via activation of aldehyde carbonyl group to the nucleophilic attack of the aniline. An hydrogen bond activation involving the hydroxyl group of choline may also participate in this process. The iminium ion 


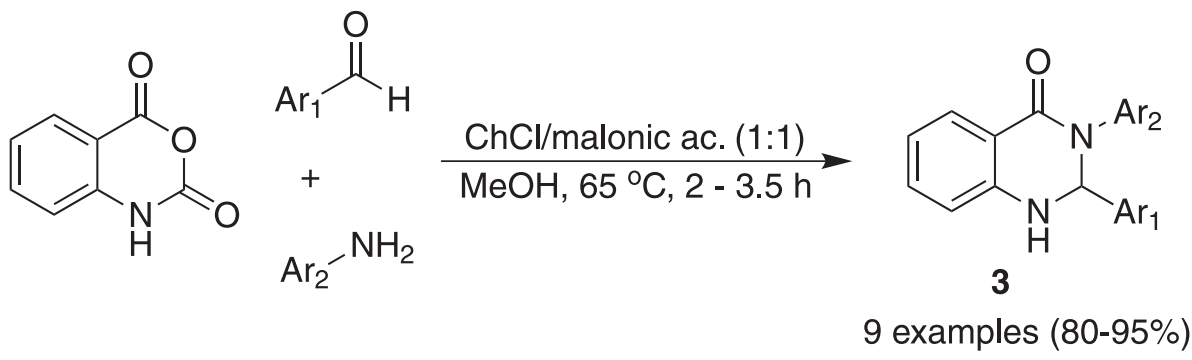<smiles>[X]c1ccc(C=O)cc1</smiles>

amines $\left(\mathrm{Ar}_{2}\right)$<smiles>[X]c1ccc(N)cc1</smiles><smiles>Cc1ccc2cccc(N)c2n1</smiles>

$\mathrm{X}=\mathrm{Cl}, \mathrm{Me}, \mathrm{OMe}$<smiles>Nc1nc(-c2ccccc2)cs1</smiles>

Scheme 2. Synthesis of 2,3-dihydroquinazolin-4(1H)-ones (3) using 20\% (v/v) of ChCl/malonic acid (1:1) in methanol.

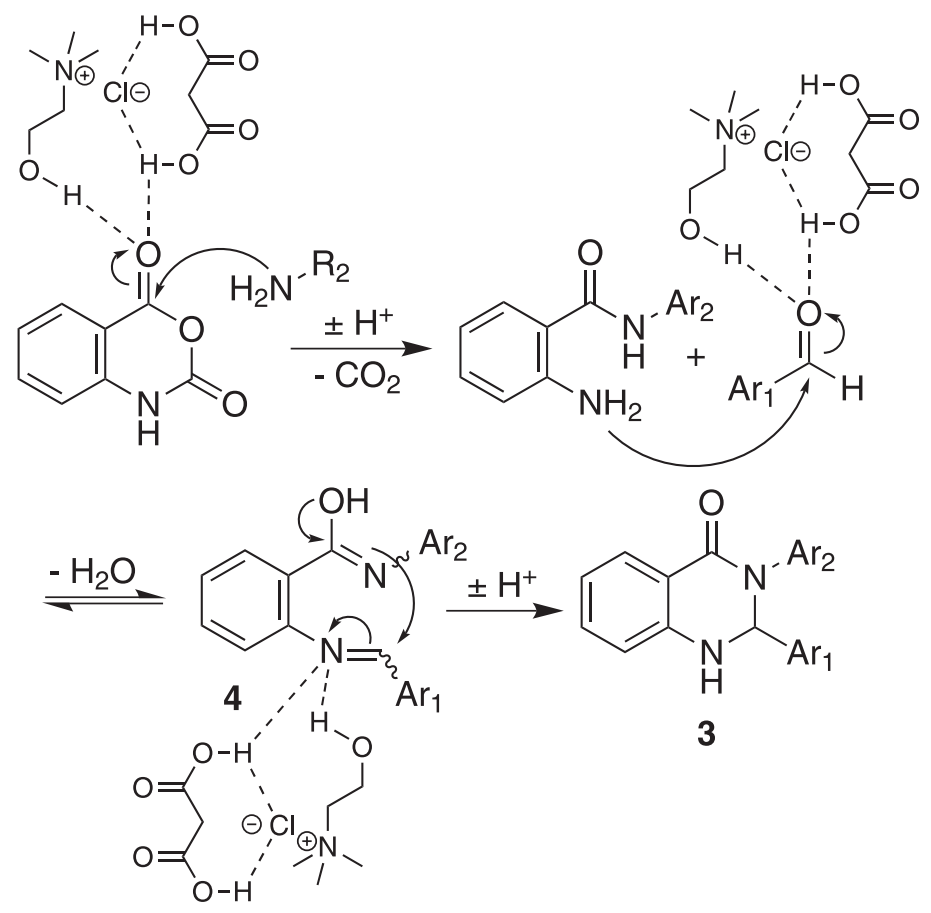

Scheme 3. Proposed mechanism for the $\mathrm{ChCl} /$ malonic acid (1:1) catalyzed synthesis of 2,3-dihydroquinazolin-4(1H)-ones (3).

intermediate thus obtained was further attacked by the indole component to furnish the product $\mathbf{6}$, upon deprotonation and rearomatization (Scheme 6). The Lewis acidic deep eutectic mixture, recovered after each run by water extraction followed by vacuum drying at $120{ }^{\circ} \mathrm{C}$ for $2 \mathrm{~h}$, could be efficiently reused in four consecutive reaction cycles.
Eutectic mixture-stabilized iron oxide nanoparticles (ferrofluid) were used as catalyst in the preparation of highly substituted imidazoles ${ }^{86}$ The 4-component reaction of 1,2-diphenylethane-1,2-diones, aromatic aldehydes, anilines and ammonium acetate was run in $\mathrm{ChCl} /$ urea (1:2) stabilized $\mathrm{Fe}_{3} \mathrm{O}_{4} \mathrm{NP}$ at $60^{\circ} \mathrm{C}$ to give a series of $1,2,4,5$-tetra- 
aryl imidazoles (7) in 60-90\% yield (Scheme 7). The same reaction furnished the products in lower yields when carried out in the absence of the catalyst system. The authors suggest that, besides the stabilization effect on the $\mathrm{Fe}_{3} \mathrm{O}_{4}$ $\mathrm{NP}$ itself, the $\mathrm{ChCl} /$ urea eutectic mixture also plays a role as an ionic media and hydrogen bond catalyst for the reaction.

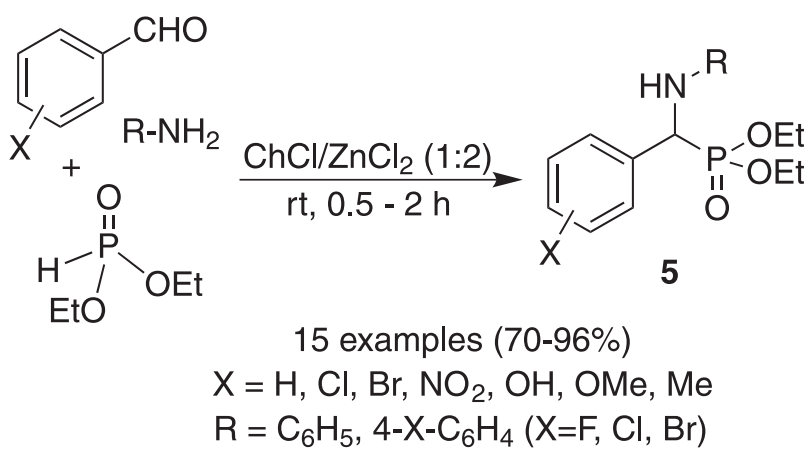

Scheme 4. Kabachmik-Fields reaction catalyzed by $\mathrm{ChCl} / \mathrm{ZnCl}_{2}(1: 2)$.

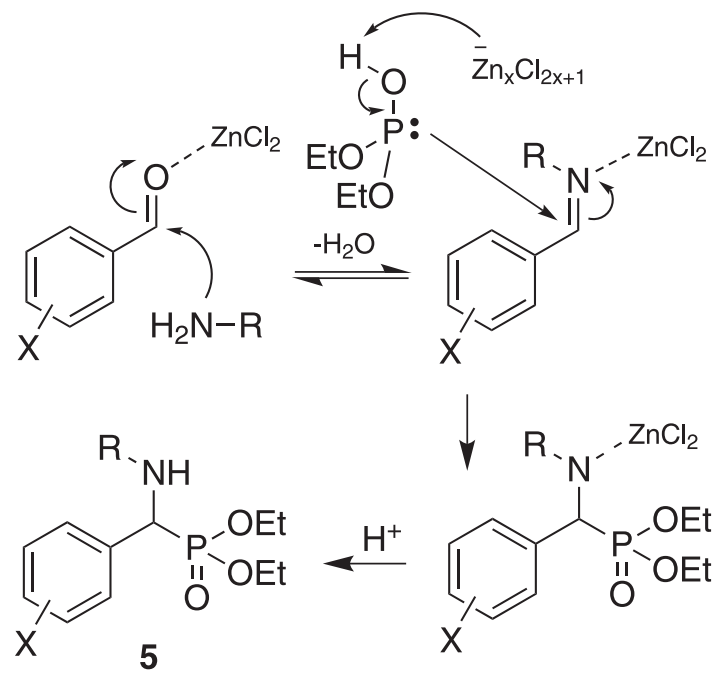

Scheme 5. Mechanism proposed for $\mathrm{ChCl} / \mathrm{ZnCl}_{2}$-catalyzed KabachmikFields reaction.
Similarly, the synthesis of 2,4,5-triaryl- $1 H$-imidazoles has also been independently described under catalysis of choline chloride/oxalic acid (1:1), ${ }^{87}$ dimethylurea/

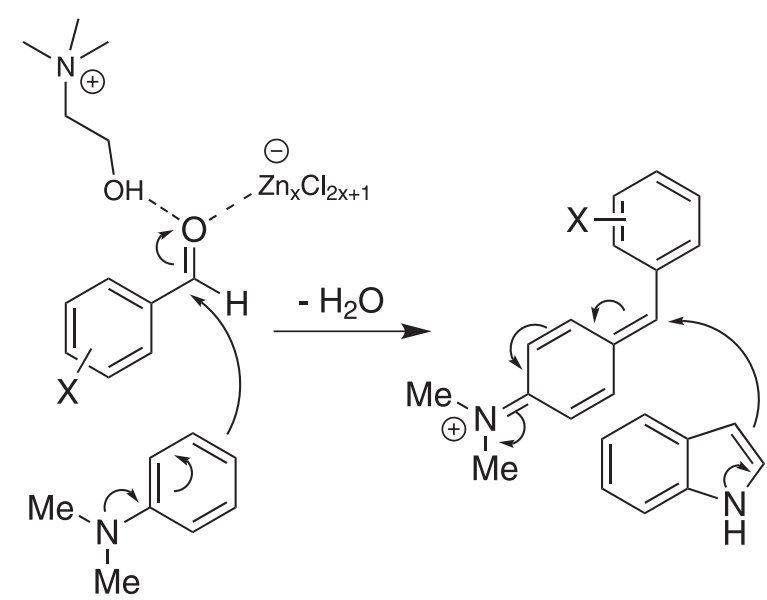<smiles>[X]c1ccccc1C(c1ccc(N(C)C)cc1)C1C=[NH+]c2ccccc21</smiles><smiles>[X]c1ccccc1C(c1ccc(N(C)C)cc1)c1c[nH]c2ccccc12</smiles>

8 examples $(43-81 \%)$
$\mathrm{X}=\mathrm{Me}, \mathrm{OMe}, \mathrm{F}, \mathrm{Cl}, \mathrm{Br}$

Scheme 6. $\mathrm{ChCl} / \mathrm{ZnCl}_{2}$ (1:3)-catalyzed synthesis of 4-[(3-indolyl)(aryl) methyl]- $N, N$-dimethylanilines (6).<smiles>[R]c1ccc(C(=O)C(=O)c2ccc([R3])cc2)cc1</smiles>

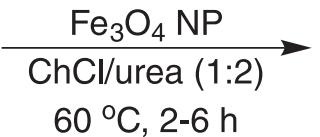<smiles>[R3]c1ccc(-c2nc(-c3ccc([R])cc3)n(-c3ccc([R])cc3)c2-c2ccc([R3])cc2)cc1</smiles>

32 examples (68-90\%)

$\mathrm{R}_{1}=\mathrm{H}, \mathrm{Cl}, \mathrm{Br}, \mathrm{NO}_{2}, \mathrm{Me}, \mathrm{OMe}, \mathrm{OH}, \mathrm{CO}_{2} \mathrm{Me}$

$\mathrm{R}_{2}=\mathrm{H}, \mathrm{Cl}, \mathrm{Br}, \mathrm{Me}, \mathrm{OMe}$

$\mathrm{R}_{3}=\mathrm{H}, \mathrm{Cl}$, OMe

Scheme 7. $\mathrm{ChCl} / \mathrm{ZnCl}_{2}$ stabilized $\mathrm{Fe}_{3} \mathrm{O}_{4} \mathrm{NP}$ as catalyst for the synthesis of tetrasubstituted imidazoles (7). 
citric acid $(3: 2)^{88}$ and $\mathrm{ChCl} / \mathrm{ZnCl}_{2}(1: 2)^{89}$ deep eutectic mixtures.

Hu et al..$^{90}$ reported a study on the use of DES in the reaction of amines, aldehydes, 1,3-dicarbonyl compounds and nitromethane to prepare highly functionalized pyrroles (8). The authors screened a series of different eutectic mixtures based on natural organic acids (i.e., citric, oxalic, itaconic, fumaric, succinic and malonic acids) and found that $\mathrm{ChCl} /$ malonic acid (1:1) mixture plays role as solvent and catalyst in this organic transformation (Scheme 8). The desired pyrroles $\mathbf{8}$ could be isolated from the reaction mixtures by extraction with ethyl acetate, whilst the recoverd DES could be reused in five cycles without significant loss of activity.

$$
\begin{gathered}
27 \text { examples (52-91\%) } \\
\mathrm{R}_{1}=\text { aryl, alkyl } \\
\mathrm{R}_{2}=\text { aryl, alkyl } \\
\mathrm{R}_{3}=\mathrm{Me}, \mathrm{Et} \\
\mathrm{R}_{4}=\mathrm{Me}, \mathrm{OMe}, \mathrm{OEt}, \mathrm{O}^{\mathrm{t}} \mathrm{Bu}
\end{gathered}
$$

Scheme 8. $\mathrm{ChCl}$-malonic acid catalyzed synthesis of polysubstituted pyrroles $(\mathbf{8})$.

The authors proposed a $\mathrm{ChCl} /$ malonic acid-promoted catalysis via hydrogen bonding activation of carbonyl group of the 1,3-dicarbonyl component, facilitating the nucleophilic attack of the aniline to form the enaminone 9 as intermediate. Similarly, acid catalysis was claimed to be involved in the Knoevenagel condensation of the nitromethane with the aromatic aldehyde component. Further Michael addition of $\mathbf{9}$ to $\mathbf{1 0}$ led to intermediate 11, which furnished the desired pyrroles upon cyclization followed by aromatization with loss of $\mathrm{HNO}$ and $\mathrm{H}_{2} \mathrm{O}$ (Scheme 9).

Rokade et al. ${ }^{91}$ also described the synthesis of annulated pyrroles using an approach focused on the catalytic role of choline chloride-based deep eutectic mixtures. The three component reaction involving different sugars with enamines (generated in situ from aromatic amines and 1,3-dicarbonyl starting materials) led to highly substituted pyrroles in excellent yields and relatively mild conditions (Scheme 10).

The utility of Mannich multicomponent reaction for the preparation of $\beta$-amino carbonyl compounds is widely acknowledged. This three-component reaction can be catalyzed by $\mathrm{ChCl} / \mathrm{ZnCl}_{2}(1: 2)$ as Lewis acid in the presence of water as solvent. ${ }^{92}$ Thus, reaction of aromatic

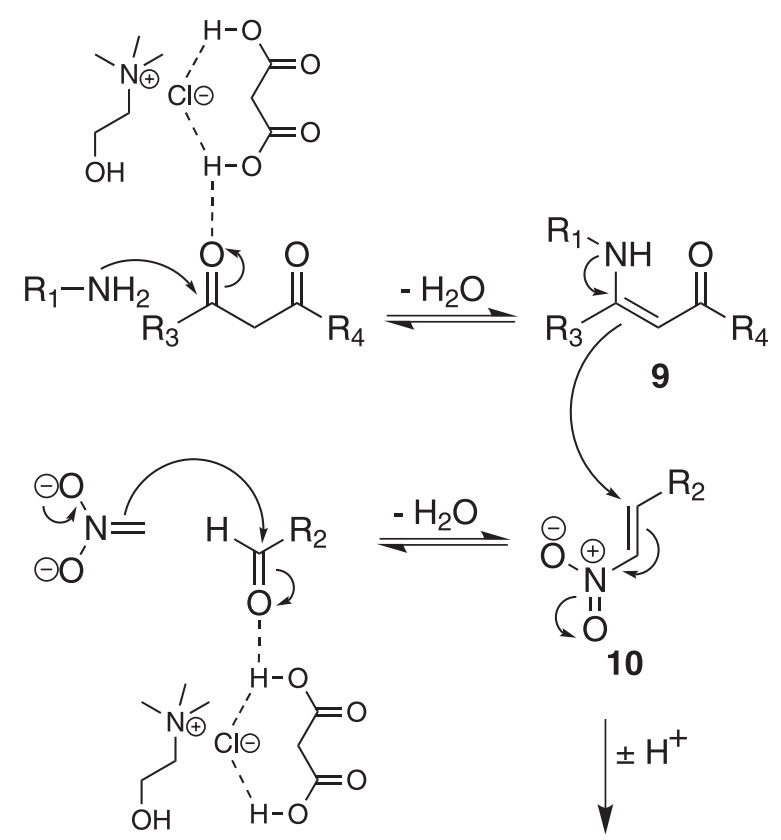<smiles>[R]C(=O)C1=C([R3])N([R])C(N(O)O)C1[R2]</smiles>

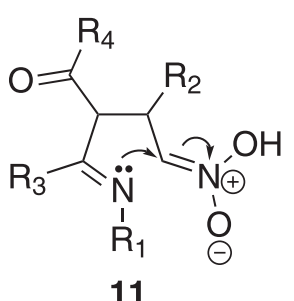<smiles>[R2]C(=O)c1c([R2])cn([B])c1[R3]</smiles>

Scheme 9. Proposed mechanism for the $\mathrm{ChCl} /$ malonic acid-catalyzed synthesis of polysubstituted pyrroles (8).<smiles>[R]C(=O)CC(C)=O</smiles>

13 examples (84-94\%)

$$
\begin{gathered}
\mathrm{R}_{1}=\mathrm{H}, \mathrm{Me} \\
\mathrm{R}_{2}=\mathrm{OEt}, \mathrm{Me}
\end{gathered}
$$

Scheme 10. Synthesis of sugar-derived pyrroles in $\mathrm{ChCl} /$ urea (1:2). 
aldehydes, anilines and enolizable ketones (acetophenone derivatives and acetone) using $5 \mathrm{~mol} \%$ of $\mathrm{ChCl} / \mathrm{ZnCl}_{2}(1: 2)$ in water at room temperature furnished the desired $\beta$-amino ketones (12) in good to excellent yields (Scheme 11). Furthermore, the deep eutectic mixture used in this study could be recovered and reused up to four consecutive runs without loss of activity.

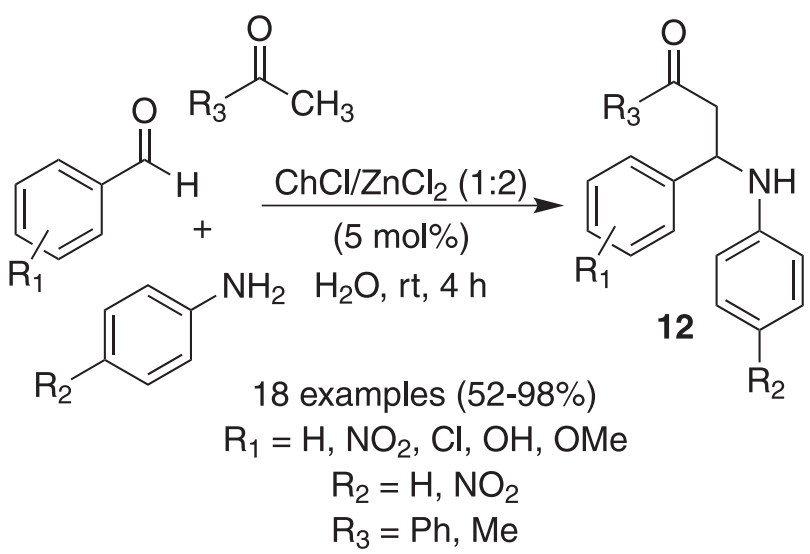

Scheme 11. Mannich reaction catalyzed by $\mathrm{ChCl} / \mathrm{ZnCl}_{2}(1: 2)$ in water.

Quinoline derivatives, an important class of nitrogenbased heterocycles with remarkable biological activities, have attracted attention of the synthetic organic chemists over the past years. ${ }^{93,94}$ Recently, Shahabi and Tavakol ${ }^{95}$ showed that the reaction of anilines with aromatic and enolizable aldehydes, catalyzed by $\mathrm{ChCl} / \mathrm{SnCl}_{2}$ (1:2), can efficiently furnish trisubstituted quinolines (13) in good to excellent yields and mild conditions (Scheme 12).

Azizi and Edrisi ${ }^{96}$ studied the use of $N$-methylpyrrolidinium-zinc chloride ( $\mathrm{HNMPCl} / \mathrm{ZnCl}_{2}$ (1:1)) deep eutectic mixture impregnated on mesoporous silica SBA-15 as heterogeneous catalyst for Mannich reactions. Thus, the reaction of ordinary aromatic aldehydes, anilines and acetophenone, catalyzed by $\mathrm{HNMPCl} / \mathrm{ZnCl}_{2} / \mathrm{SBA}-15$ at $60^{\circ} \mathrm{C}$ for $5-8 \mathrm{~h}$, led to a series of $\beta$-aminoketones in good to excellent yields (Scheme 13). The catalyst system has efficiency compared to other standard methods described in the literature, but the authors highlighted some advantages of their method, such as nontoxicity, low catalyst loadings, and reuse of the catalyst for five consecutive reaction cycles.

Later, the same authors reported the synthesis of 1-aminoalkyl-2-naphthols (14) from the reaction of $\beta$-naphthol, secondary amines and aldehydes using $\mathrm{ChCl} /$ urea (1:2) as solvent (Scheme 14). ${ }^{97}$

\subsection{MCR based on Knoevenagel condensation}

Knoevenagel condensation is a base-catalyzed reaction of aldehydes or ketones with active methylene compounds such as malonic esters, cyanoesters or dinitriles, among others. This important reaction is widely involved in several organic transformations to access biologically active oxygen and nitrogen-based heterocyclic compounds

$$
\begin{aligned}
& \text { 事 } \\
& 16 \text { examples (54-96\%) } \\
& \mathrm{R}_{1}=\mathrm{H}, \mathrm{Cl}, \mathrm{Br} \\
& \mathrm{R}_{2}=\mathrm{H}, \mathrm{CH}_{3}, \mathrm{C}_{2} \mathrm{H}_{5}, \mathrm{C}_{5} \mathrm{H}_{11} \\
& \mathrm{X}=\mathrm{H}, \mathrm{Me}, \mathrm{OMe}, \mathrm{NO}_{2}, \mathrm{OH}, \mathrm{Cl} \text {, }
\end{aligned}
$$

Scheme 12. Synthesis of quinolines (13) catalyzed by $\mathrm{ChCl} / \mathrm{SnCl}_{2}(1: 2)$ in solventless conditions.

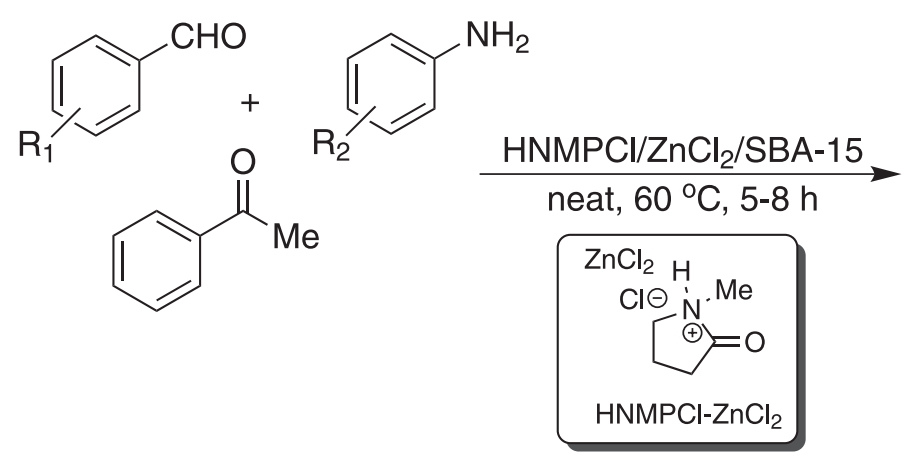<smiles>[R6]c1ccccc1NC(CC(=O)c1ccccc1)c1ccc(Br)cc1</smiles>

Scheme 13. Heterogeneous catalyst $\mathrm{HNMPCl} / \mathrm{ZnCl}_{2} / \mathrm{SBA}-15$ for Mannich reactions. 


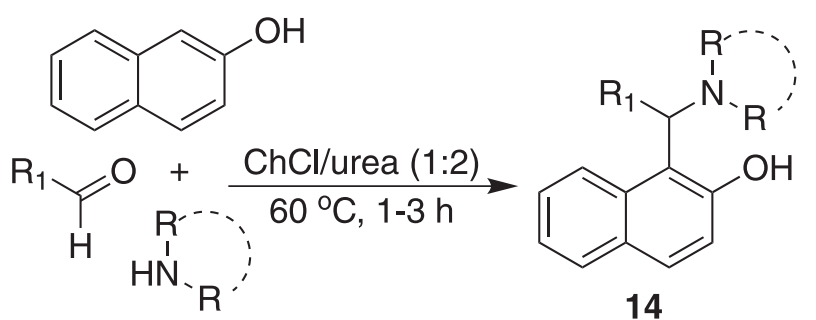

21 examples (72-96\%)

$\mathrm{R}_{1}=\mathrm{H}, \mathrm{OMe}, \mathrm{Me}, \mathrm{Cl}, \mathrm{Br}, \mathrm{CO}_{2} \mathrm{Me}$

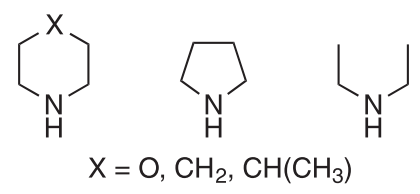

Scheme 14. Synthesis of 1-aminoalkyl-2-naphthols (14) in $\mathrm{ChCl} / \mathrm{urea}$ $(1: 2)$.

such pyranes, chromenes, indoles, 1,4-dihydropyridines and related compounds. In this section, we will describe the studies of multicomponent reactions in deep eutectic mixtures in which the Knoevenagel condensation is part of the mechanism of the reaction.

In 2013, Azizi et al.$^{98}$ synthesized benzopyran derivative 15 using benzaldehyde, malononitrile and dimedone as starting materials. They firstly screened different deep eutectic mixtures as catalysts for this transformation and verified that $\mathrm{ChCl} / \mathrm{urea}(1: 2)$ led to the best results (Scheme 15). The scope of $\mathrm{ChCl} /$ urea (1:2) mixture as catalyst for this transformation was further explored using different substituted aromatic aldehydes as starting materials, giving rise to several benzopyran derivatives in good to excellent yields (75-95\%).<smiles>CC1(C)CC(=O)CC(=O)C1</smiles>

Scheme 15. DES screening for the preparation of benzopyran derivatives (15).

The role of the DES in the mechanism of this reaction is not fully clear, but many authors suggested that the catalysis is due to Brønsted basicity of urea and its hydrogen bonding ability, making easier the deprotonation of the active methylene compound involved in the Knoevenagel condensation, as well as facilitating the nucleophilic attack to the carbonyl compound (Scheme 16). Initially, the attack of malononitrile to benzaldehyde is assisted by the eutectic mixture, leading to intermediate 16, which upon dehydration furnished the Knoevenagel adduct 17. This intermediate is attacked by the enol form of the dimedone, followed by an intramolecular cyclization step leading to 18, which further tautomerizes to the desired benzopyran product.

In the same year, Pednekar et al. ${ }^{99}$ studied a similar approach using ethyl acetoacetate as $\mathrm{CH}_{2}$-acid component. Thus, the reaction of dimedone, aliphatic and aromatic aldehydes, ethyl acetoacetate and $\mathrm{NH}_{4} \mathrm{OAc}$ in $\mathrm{ChCl} /$ urea $(1: 2)$ at $60^{\circ} \mathrm{C}$ for $20 \mathrm{~min}$ led to the corresponding

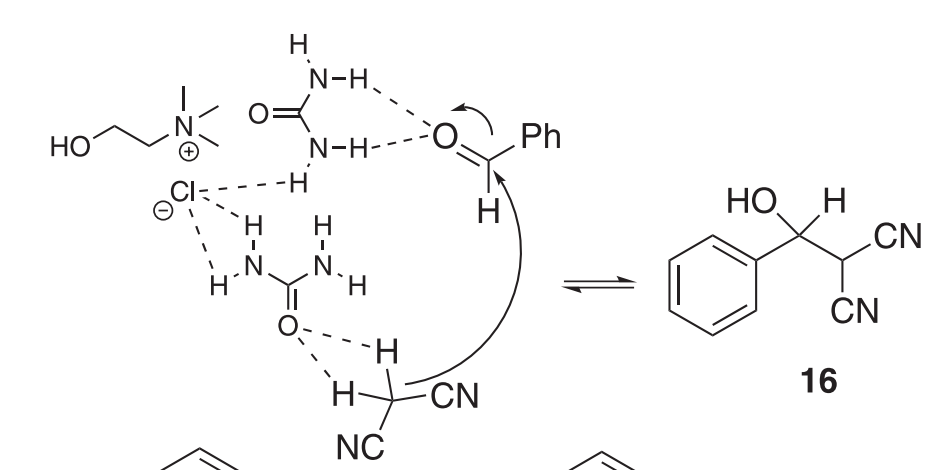<smiles>CC1(C)CC(=O)C(C(c2ccccc2)C(C#N)C(C#N)C[PH2+])C(=O)C1</smiles>

Scheme 16. $\mathrm{ChCl} /$ urea catalyzed mechanism for the synthesis of benzopyrans (15).

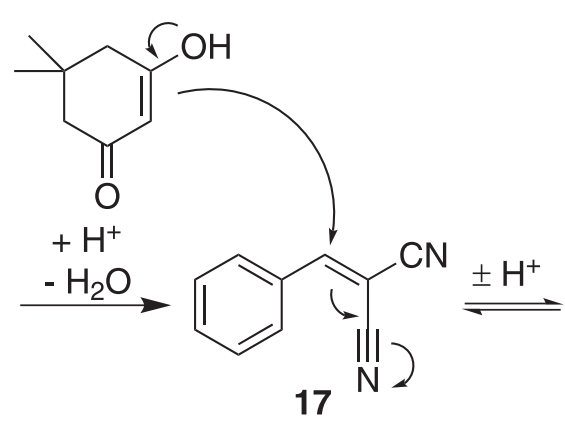<smiles>C#CC1(C)CC(=O)C2=C(C1)OC(N)=C(C#N)C2c1ccccc1</smiles>

15 
7,8-dihydroquinolin-5(1H,4H,6H)-ones (19) in good to excellent yields (Scheme 17).<smiles>CC1(C)CC(=O)CC(=O)C1</smiles><smiles>CCOC(=O)CC(C)=O</smiles>

14 examples $(74-95 \%)$

$\mathrm{R}=\mathrm{H}$, 4-Me, 4-OMe, 4-OH, $4-\mathrm{NO}_{2}, 4-\mathrm{NMe}_{2}, 4-\mathrm{Cl}, 3-\mathrm{NO}_{2}$, 3-OMe, 2-Cl

Scheme 17. Synthesis of 7,8-dihydroquinolin-5(1H,4H,6H)-ones (19) in $\mathrm{ChCl} /$ urea $(1: 2)$.
In a similar study, Chaskar ${ }^{100}$ described the synthesis of 2-amino- $4 H$-chromenes (20) and pyranocoumarins (21) using $20 \% \mathrm{ChCl} /$ urea $(1: 2)$ in water (v/v) as DES. The author tested several aromatic aldehydes, two different $\mathrm{CH}_{2}$-acid components (malononitrile and ethyl cyanoacetate) and dimedone or 4-hydroxycoumarin as 1,3-dicarbonyl compounds, obtaining the desired products in good to excellent yields (Scheme 18).

Azizi et al. ${ }^{101}$ reported a chemoselective synthesis of tetraketones (22) and xanthenes (23) in choline chloride-based DES, using a pseudo-three component reaction between 1,3-dicarbonyl compounds and aromatic aldehydes. The authors carried out a careful screening of eutectic mixtures to obtain both types of products. Higher yields of $\mathbf{2 3}$ were obtained when $\mathrm{ChCl} / \mathrm{ZnCl}_{2}$ (1:2) was used as DES whilst 22 was preferentially prepared in $\mathrm{ChCl} /$ urea (1:2) (Scheme 19).

Two years later, a similar transformation was carefully investigated by Navarro et al., ${ }^{102}$ who described the use of<smiles></smiles>

Scheme 18. Synthesis of 2-amino- $4 H$-chromenes (20) and pyranocoumarins (21) using aqueous solution of $\mathrm{ChCl} /$ urea.<smiles>[R]c1ccc(C([CH2+])=O)cc1</smiles>

Scheme 19. Pseudo-three component reaction in choline chloride-based deep eutectic solvents. 
deep eutectic mixtures based on sodium acetate trihydrate and urea as benign reaction media for the Biginelli-like reactions. The reaction of 2 equivalents of dimedone with aromatic aldehydes in $\mathrm{NaOAc}_{3} \mathrm{H}_{2} \mathrm{O} /$ urea $(2: 3)$ at $60{ }^{\circ} \mathrm{C}$ for $2 \mathrm{~h}$ led to a series of tetraketone derivatives 22 in good to excellent yields (Scheme 20; exemplified for $p$-chlorobenzaldehyde). However, it was also noticed an unexpected formation of hexahydroacridine-1,8-dione products (24) when additional urea (1 molar equivalent) was added to the media and the reaction was carried out at $90{ }^{\circ} \mathrm{C}$ for prolonged periods of time.

Although the authors showed that the $\mathrm{NaOAc} .3 \mathrm{H}_{2} \mathrm{O}$ /urea (2:3) mixture is stable in $\mathrm{T}<130^{\circ} \mathrm{C}$ (as indicated by thermal analysis), they also suggested an in situ production of $\mathrm{NH}_{3}$ upon slow decomposition of urea under reaction conditions. Simeonov and Afonso ${ }^{103}$ also observed a decomposition of sorbitol/urea deep eutectic mixture under temperatures below $100{ }^{\circ} \mathrm{C}$, and the in situ produced ammonia was involved in the synthesis of 1,4-dihydropyridines via Hantzsch multicomponent reaction. The presence of ammonia in the reaction medium could explain the formation of $\mathbf{2 4}$, as it can react with the intermediate tetraketones 22 at higher temperatures. In fact, hexahydroacridine-1,8-dione products (24) could be obtained in $82 \%$ yield when 22 was heated at $100{ }^{\circ} \mathrm{C}$ in the presence of $\mathrm{NaOAc} .3 \mathrm{H}_{2} \mathrm{O} /$ urea (2:3) for $6 \mathrm{~h}$ (see Scheme 20).

Two distinguished groups published studies on the use of DES in the synthesis of spirooxindoles (25-27). This scaffold is widespread in natural products such as alkaloids, lactones and terpenoids, as well as synthetic compounds with important biological properties such as antiviral, ${ }^{104}$ including anti-HIV, ${ }^{105}$ MDM2 inhibitors and anticancer, ${ }^{106}$ antitubercular, ${ }^{107}$ antimalarial, ${ }^{108}$ antibacterial, ${ }^{109-111}$ and progesterone receptor modulator. ${ }^{112}$

Azizi et al. ${ }^{113}$ optimized the conditions for the threecomponent reaction of isatin, malononitrile or cyanoacetic esters, and dimedone, 4-hydroxycoumarin or 1-naphthol using $\mathrm{ChCl} /$ urea (1:2) as solvent and catalyst (Scheme 21). Higher yields were observed when malononitrile was used as $\mathrm{CH}_{2}$-active component (compared to cyanoacetic esters). Although the exact role of the choline chloride/ urea in the mechanism of this transformation is not fully understood, the authors suggested an acid-catalyzed Knoevenagel condensation between isatin and the $\mathrm{CH}_{2}$-acid component, followed by the Michael addition of the enol form of the 1,3-dicarbonyl compound and further intramolecular cyclization to furnish the desired spirooxindole.

In the same year, Rajawat et al. ${ }^{114}$ reported a variation of this process using phthalic anhydride and isatin in the presence of hydrazine hydrate and several different 1,3-dicarbonyl components (dimedone, barbituric acid, indan-1,3-dione and 4-hydroxycoumarin). Thus, four structurally diverse spirooxindoles (28-31) were prepared in good to excellent yields using $\mathrm{ChCl} / \mathrm{urea}(1: 2)$ at $80{ }^{\circ} \mathrm{C}$ for 20 to $40 \mathrm{~min}$ (Scheme 22).

The authors suggested a mechanism based on the choline chloride/urea acid catalysis of a nucleophilic addition of hydrazine to phthalic anhydride, leading to the 2,3-dihydrophthalazine-1,4-dione (32). The DES also plays a role as acid catalyst for the Knoevenagel condensation of 1,3-dicarbonyl compound with isatin. Further addition of 32 to the Knoevenagel adduct 33, followed by cyclization and dehydration steps, led to the desired spirooxindole derivatives (Scheme 23; exemplified by indan-1,3-dione as 1,3-dicarbonyl component).

In 2014, Swaroop et al. ${ }^{15}$ described a straightforward synthesis of $4 H$-pyrano[2,3-c]pyrazoles (34-35) in deep eutectic solvents under mild conditions. The reaction of hydrazine derivatives, malononitrile, 1,3-dicarbonyl compounds and aromatic aldehydes in $\mathrm{ChCl} /$ urea (1:2) at room temperature for short period of time furnished

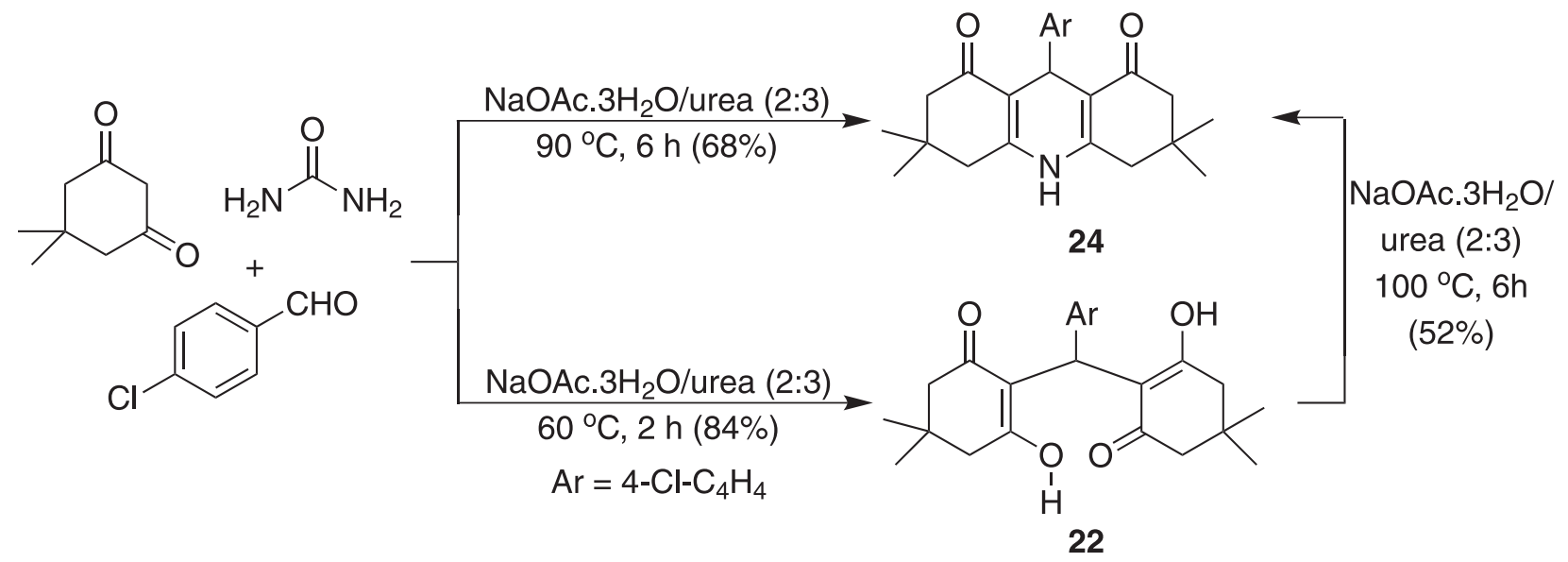

Scheme 20. Biginelli-like reactions in sodium acetate trihydrate/urea (2:3). 


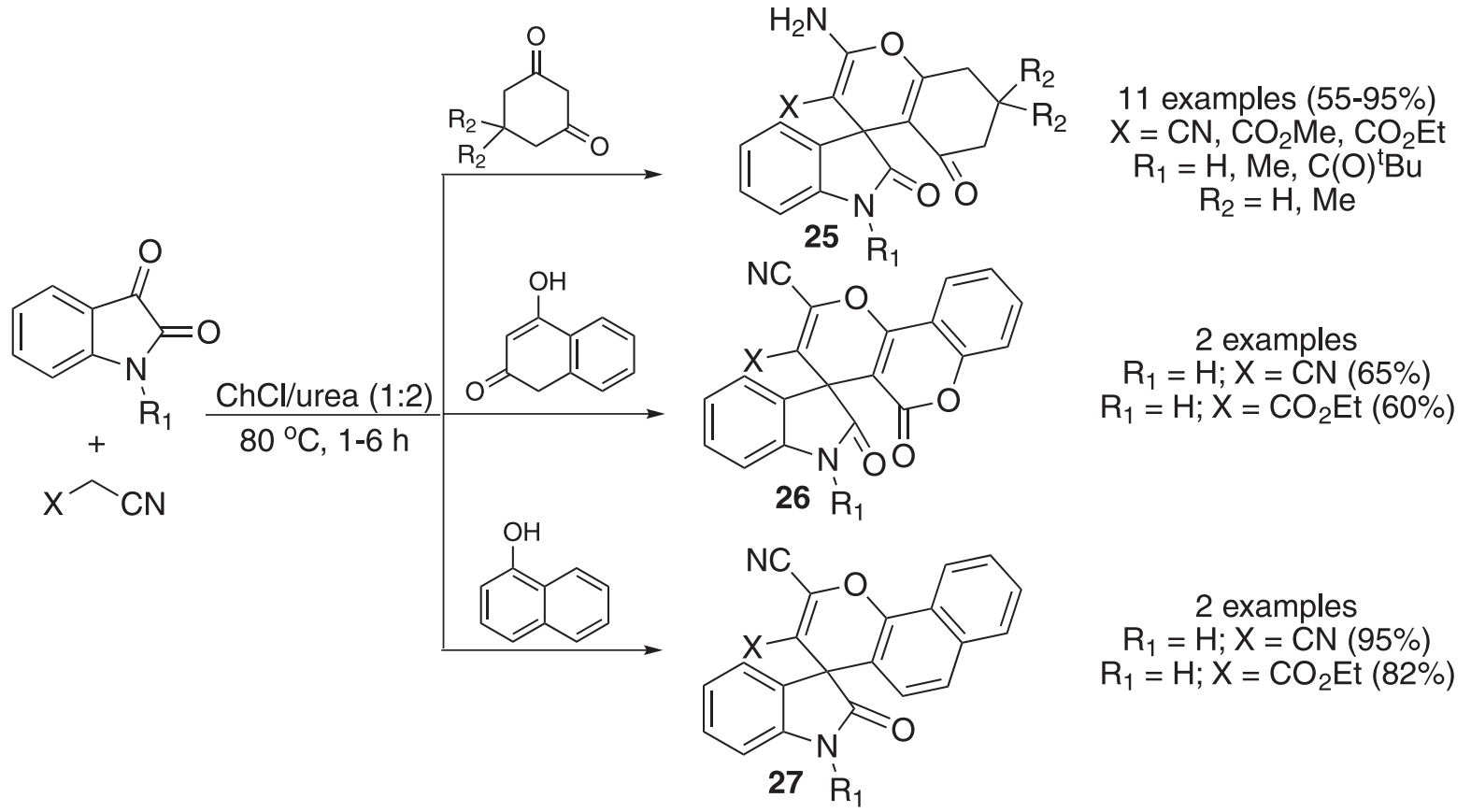

Scheme 21. One-pot synthesis of spirooxindole derivatives (25-27) in $\mathrm{ChCl} / \mathrm{urea}(1: 2)$.

the desired heterocycles in good to excellent yields (Scheme 24).

Two years later, two independent groups described almost simultaneously an approach to $4 \mathrm{H}$-pyrano [2,3-c]pyrazoles, using the same deep eutectic mixture (i.e., $\mathrm{ChCl} /$ urea (1:2)) with a slight modification on the reaction temperature $\left(\mathrm{T}=80^{\circ} \mathrm{C}\right) .{ }^{116,117}$

The mechanism generally accepted for this transformation is based on the ability of DES to be involved in hydrogen-bonding with carbonyl compounds, enhancing the electrophilic character of the carbonyl carbons. Thus, the formation of pyrazolin-5-one (36) as intermediate, upon reaction of the 1,3-dicarbonyl component with hydrazine, can be acid-catalyzed by the $\mathrm{ChCl} /$ urea solvent (Scheme 25). Also, an acid-catalyzed Knoevenagel condensation between the aldehyde and malononitrile explains the formation of $\mathbf{3 7}$, which reacts with $\mathbf{3 6}$ to furnish the desired $4 H$-pyrano[2,3-c]pyrazoles. ${ }^{116}$

$4 H$-Chromenes (38) can also be easily prepared via multicomponent reactions catalyzed by deep eutectic mixtures. Azizi et al. ${ }^{118}$ described a mild protocol for the condensation of salicylaldehyde derivatives, malononitrile and different nucleophiles (thiols, amines, nitrile and indoles) in $\mathrm{ChCl} /$ urea (1:2) as green solvent (Table 3). Using thiophenol $(\mathrm{PhSH})$ as nucleophile, both electron rich and poor salicylaldehydes afforded $4 \mathrm{H}$-chromenes in good yields (entries 1-3). However, when butane-2-thiol was used, the corresponding $4 \mathrm{H}$-chromene was obtained in only $45 \%$ yield (entry 4). Trimethylsilyl cyanide (TMSCN, entries 5-7) and piperidine (entries 8-10) were also evaluated as nucleophiles.
More recently, Krishnammagari et al. ${ }^{119}$ reported a similar protocol with the use of dialkyl phosphites as nucleophiles to obtain 2 -amino- $4 H$-chromen-4-yl phosphonate derivatives (39) (Scheme 26).

Nitrogen-containing heterocycles represent an important class of biologically active compounds, which exhibited a broad range of applications in both Medicinal Chemistry and Biology. The use of deep eutectic mixtures as solvents and/or catalysts in the preparation of such compounds is remarkable and they have become very popular as alternative and green reaction media for the preparation of compounds containing the indole, pyridine, quinazolinone, naphthyridine, and pyrazole rings, among many others.

In 2013, Siddalingamurthy et al. ${ }^{120}$ studied the synthesis of indole-3-propanamide derivatives (40) using $\mathrm{ChCl} / \mathrm{urea}$ as catalyst. These compounds are important precursors to several biologically active molecules, such as tyrosine kinase inhibitors (treatment of brain disorders), ${ }^{121}$ epidermal growth factor receptor, ${ }^{122}$ immunosuppressive, ${ }^{123}$ anti-allergic ${ }^{124}$ and anti-inflammatory ${ }^{125}$ activities. The described method involves $N$-methylindole, several aldehydes and Meldrum's acid, heated in a solution of $20 \mathrm{~mol} \%$ of $\mathrm{ChCl} /$ urea (1:2) in acetonitrile (Scheme 27).

In 2017, Aryan et al. ${ }^{126}$ described a new method to prepare pyrazole-4-carbonitrile compounds (41 and $\mathbf{4 2}$ ) using biocompatible glucose-based deep eutectic solvents. Thus, the reaction of hydrazine derivatives, malononitrile and aromatic aldehydes, under heating at room temperature in glucose/urea (1:5), afforded the desired pyrazoles in good to excellent yields (Scheme 28). Also recently, Kamble 


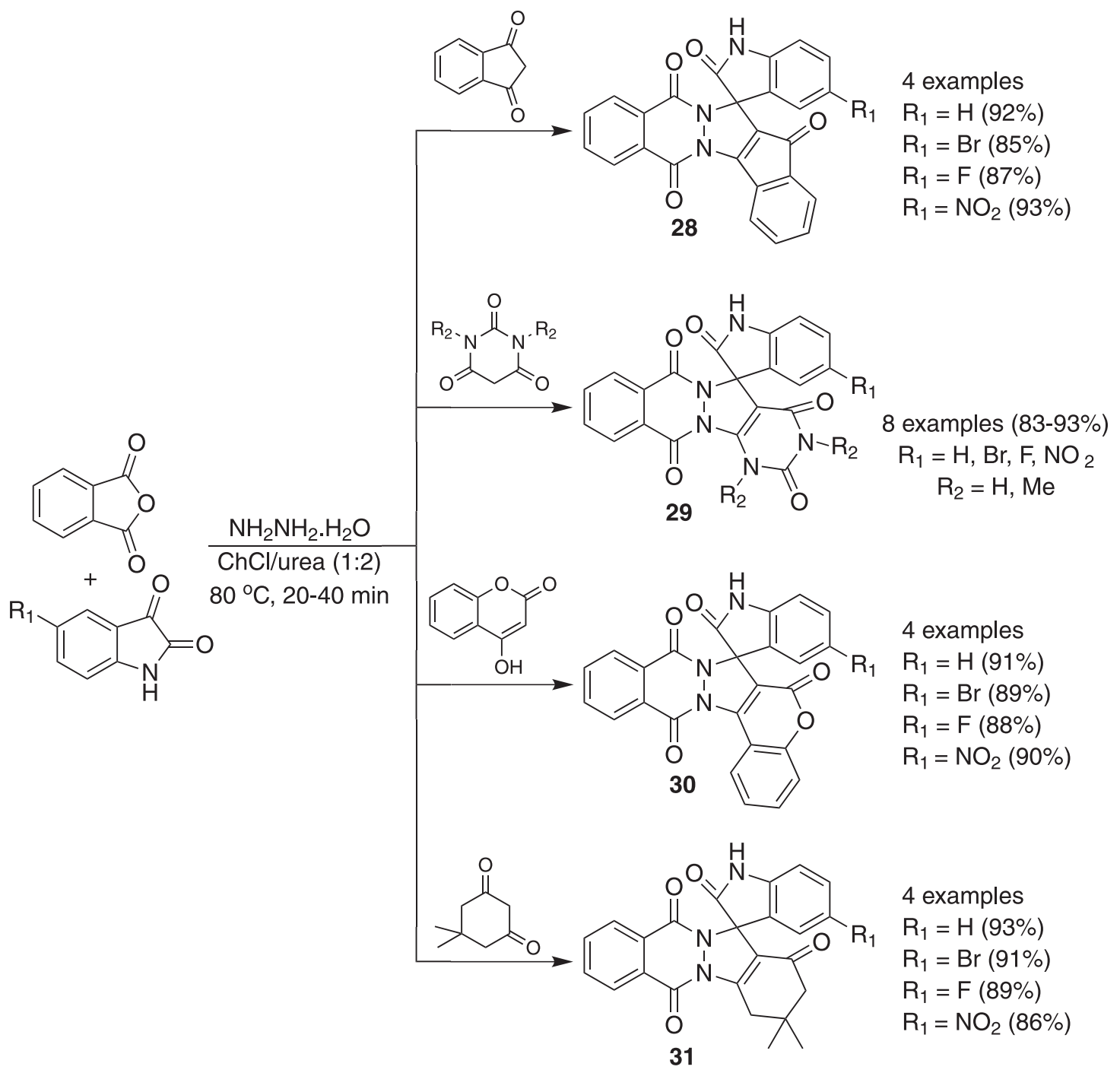

Scheme 22. Preparation of diverse spirooxindole derivatives (28-31) in $\mathrm{ChCl} /$ urea (1:2).

and Shankarling ${ }^{127}$ reported a similar approach for the ultrasound-promoted Knorr pyrazole synthesis using a combination of DES and water.

Four independent groups described deep eutectic mixture-catalyzed multicomponent reaction approaches to obtain complex polycyclic heterocycles such as 13-aryl$13 H$-benzo $g$ ]benzothiazolo[2,3- $b$ ]quinazoline-5,4-diones $\mathbf{( 4 3 )},{ }^{128}$ indeno-fused pyrido[2,3-d]pyrimidines $(\mathbf{4 4}),{ }^{129}$ 3,4,5,12-tetrahydrobenzo[4,5]imidazo[2,1-b]quinazolin$1(2 \mathrm{H})$-ones $(\mathbf{4 5})^{130}$ and pyrazolopyranopyrimidines (46). ${ }^{131}$ The reactions involved the key condensation step of a Knoevenagel adduct with different amines in $\mathrm{ChCl}$ /urea (1:2), oxalic acid dihydrate/proline (1:1) or $\mathrm{ChCl} /$ glycerol (1:2) as reaction media and catalyst (Scheme 29).

Two pseudo-four multicomponent reactions were recently designed to furnish cyclohexa-1,3-dienamines (47) ${ }^{132}$ and highly substituted pyridines (48). ${ }^{133}$ In 2017, Azizi et al ${ }^{132}$ described the reaction of aromatic aldehydes, two equivalents of malononitrile and ketones, in $\mathrm{ChCl} /$ urea (1:2) at $50{ }^{\circ} \mathrm{C}$, which led to the desired cyclohexa-1,3-dienamines (47) in good to excellent yields (Scheme 30). According to the authors, the deep eutectic mixture could be recycled and reused up to five reaction cycles without loss of activity. Similarly, highly substituted pyridines $(\mathbf{4 8})$ were synthesized by the combination of aromatic aldehydes, malononitrile (two equivalents) and aromatic thiols in $\mathrm{ChCl} /$ urea (1:2) at $60{ }^{\circ} \mathrm{C}$ (Scheme 30). ${ }^{133}$

Highly substituted naphthyridines can also be obtained by DES-mediated multicomponent transformations. Shaabani et al. ${ }^{134}$ recently described the domino 4-component reaction of equimolar mixtures of diamines, 1,1-bis(methylthio)-2-nitroethylene (49), 2-amino-1-ene1,1,3-tricarbonitrile (50) and carbonyl compounds (aldehydes or ketones) using $\mathrm{ChCl} /$ urea (1:2) at $90^{\circ} \mathrm{C}$ for 3-4 h. Under these conditions, a series of complex heterocycles could be obtained in good to excellent yields (Scheme 31, 


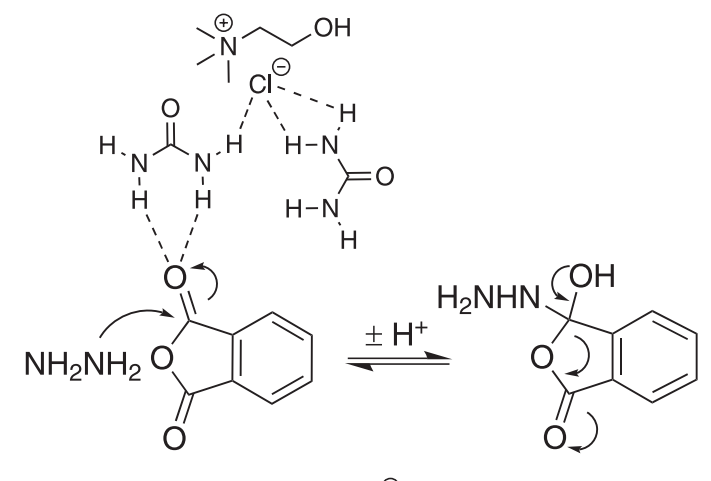

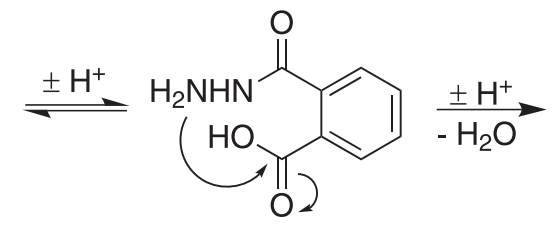<smiles>O=c1[nH][nH]c(=O)c2ccccc12</smiles><smiles>O=C1C(O)=C(O)c2ccccc21</smiles>

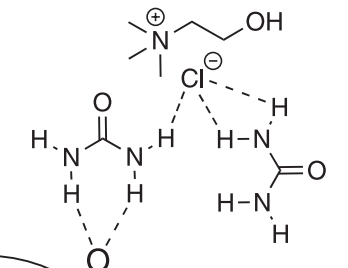<smiles>CCCC1=CCCCC1=O</smiles><smiles>CN(CCO)C(C)(C)C</smiles><smiles>CC1C(=O)Nc2ccccc21</smiles>

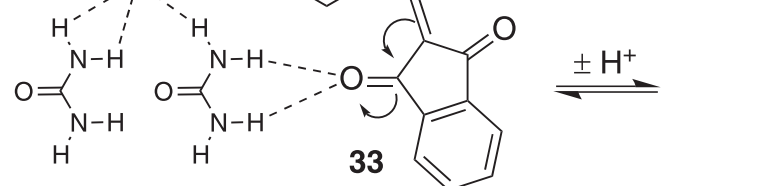

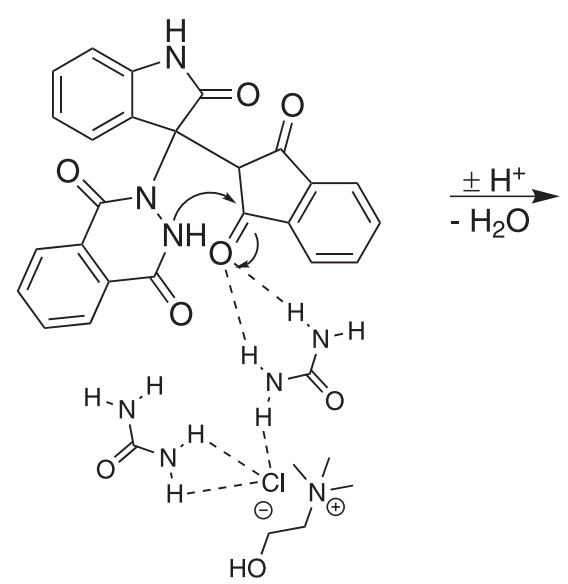<smiles>O=C1C2=C(c3ccccc31)n1c(=O)c3ccccc3c(=O)n1C21C(=O)Nc2ccccc21</smiles>

Scheme 23. Proposed mechanism of the formation of spirooxindoles derivatives.<smiles>[R7]NN</smiles><smiles>[X]c1ccc(C=O)cc1</smiles><smiles>O=Cc1ccco1</smiles><smiles>O=Cc1cccnc1</smiles><smiles>[R2]c1nn([R7])c2c1C(Br)C(C#N)=C(N)O2</smiles>

17 examples (62-95\%)

$$
\begin{aligned}
& \mathrm{R}_{1}=\mathrm{H}, \mathrm{C}_{6} \mathrm{H}_{5} \\
& \mathrm{R}_{2}=\mathrm{Me}, \mathrm{IPr}
\end{aligned}
$$

$\mathrm{X}=\mathrm{H}, 4-\mathrm{NO}_{2}$, 4-OMe, 4-Et, 4-OEt, 4-NMe $\mathrm{N}_{2}$, 3,4-diOMe, 3,4,5-triOMe

Scheme 24. $\mathrm{ChCl} /$ urea-catalyzed multicomponent synthesis of $4 H$-pyrano[2,3-c]pyrazoles (34-35). 
<smiles>CC(=O)CC(=O)CC=C(C)C</smiles>

Scheme 25. Proposed mechanism for the $\mathrm{ChCl} /$ urea-catalyzed multicomponent synthesis of $4 H$-pyrano[2,3-c]pyrazoles.

exemplified for indoline-2,3-dione). The authors suggested the mechanism shown in Scheme 32, which involves the nucleophilic attack of enamine $\mathbf{5 1}$ to the Knoevenagel adduct 52. Two consecutive DES-catalyzed cyclizations of intermediates $\mathbf{5 3}$ and $\mathbf{5 4}$ furnish the desired naphthyridines.

\subsection{MCR based on nucleophilic attack of isocyanides}

Isocyanides are common reagents for an important class of multicomponent reactions, the so-called isocyanide-based multicomponent reactions (IMCR). ${ }^{135-138}$ Due to the unique properties of the isocyano group, with an electrophile and a nucleophile center in the same molecule, this class of reagents can be used in interesting different approaches to the synthesis of heterocycle compounds. ${ }^{47,139}$ The first IMCR was described by the Italian chemist Mario Passerini ${ }^{39}$ in the
Table 3. Syntheses of $4 H$-chromenes (38) in $\mathrm{ChCl} /$ urea (1:2) using salicylaldehyde derivatives, malononitrile and different nucleophiles

\begin{tabular}{lccc} 
& & \\
\hline entry & $\mathrm{R}$ & Nucleophile & Yield / \% \\
\hline 1 & $\mathrm{H}$ & $\mathrm{PhSH}$ & 98 \\
2 & $5-\mathrm{Br}$ & $\mathrm{PhSH}$ & 95 \\
4 & $3-\mathrm{OMe}$ & $\mathrm{PhSH}$ & 95 \\
5 & $\mathrm{H}$ & butane-2-thiol & 45 \\
6 & $\mathrm{H}$ & TMSCN & 95 \\
7 & $5-\mathrm{Br}$ & TMSCN & 90 \\
8 & $3-\mathrm{OMe}$ & TMSCN & 82 \\
9 & $\mathrm{H}$ & piperidine & 78 \\
10 & $5-\mathrm{Br}$ & piperidine & 72 \\
\hline
\end{tabular}

PhSH: thiophenol; TMSCN: trimethylsilyl cyanide.

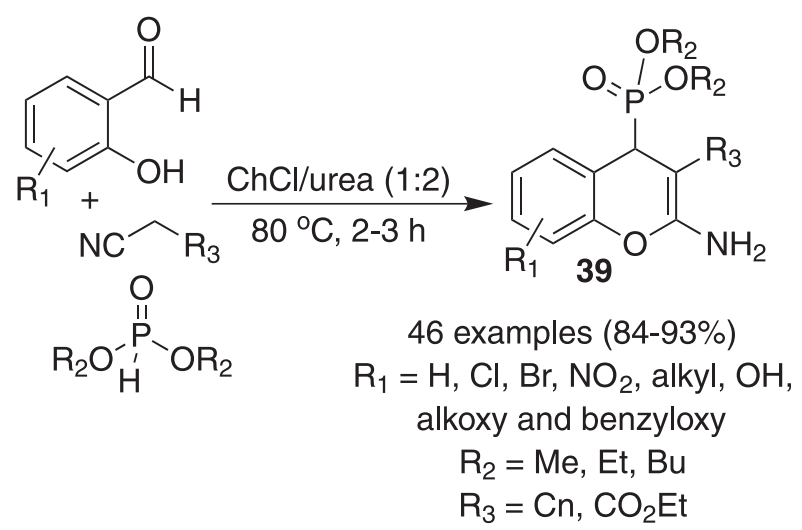

Scheme 26. Synthesis of 2 -amino- $4 H$-chromen-4-yl phosphonate derivatives (39) in $\mathrm{ChCl} /$ urea (1:2).

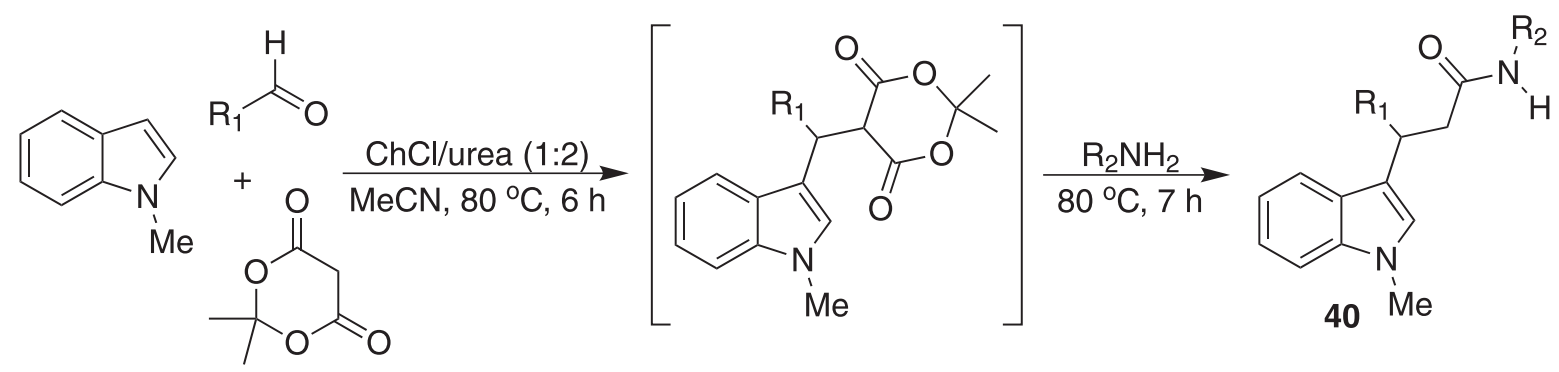

12 examples (74-92\%)

$\mathrm{R}_{1}=2$-phenylacetaldehyde, quinoline-

3-carbaldehyde, 2-ethoxybenzaldehyde

$\mathrm{R}_{2}=$ benzylamine, 2-chlorobenzylamine, 2-methoxyethanamine

Scheme 27. Preparation of indole-3-propanamide derivatives (40) using $\mathrm{ChCl} / \mathrm{urea}(1: 2)$ as catalyst. 


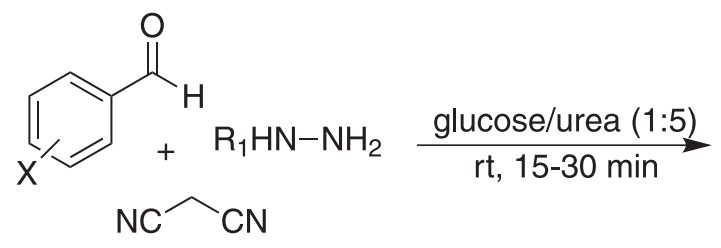<smiles>N#Cc1c(-c2ccccc2)n[nH]c1N</smiles>

(when $\mathrm{R}_{1}=\mathrm{H}$ )<smiles>[X]c1ccc(-c2nn(-c3ccccc3)c(N)c2C#N)cc1</smiles>

(when $\mathrm{R}_{1}=\mathrm{Ph}$ )

16 examples (83-96\%)

$\mathrm{R}_{1}=\mathrm{H}, \mathrm{C}_{6} \mathrm{H}_{5}$

$\mathrm{X}=\mathrm{H}, 2-\mathrm{OH}, 2-\mathrm{Cl}, 4-\mathrm{Cl}, 4-\mathrm{CN}$,

4- $\mathrm{NHC}(\mathrm{O}) \mathrm{Me}, 3-\mathrm{NO}_{2}$

Scheme 28. Preparation of pyrazole-4-carbonitrile derivatives (41 and $\mathbf{4 2}$ ) using glucose/urea (1:5) as reaction media.<smiles>Nc1nc2ccccc2s1</smiles><smiles>CC(C)(C)c1ccccc1</smiles>

19 examples (85-95\%)

Ar = phenyl, substituted<smiles>O=C1CC(=O)c2ccccc21</smiles><smiles>Nc1cc(=O)[nH]c(=O)[nH]1</smiles>
phenyl, 2-furanyl, 2-thiophenyl<smiles>Nc1nc2ccccc2[nH]1</smiles><smiles>CCCCC1C2=C(Nc3[nH]c(=O)[nH]c(=O)c31)c1ccccc1C2=O</smiles>

13 examples (85-95\%)

$\mathrm{Ar}=$ phenyl, substituted phenyl

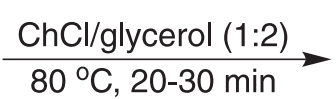<smiles>O=C1CCCC2=C1C(Br)n1c(nc3ccccc31)N2</smiles>

45

16 examples (52-91\%) $\mathrm{Ar}=$ phenyl, substituted phenyl,<smiles>[R17]N1C(=O)CC(=O)N([R7])C1=O</smiles>
1-naphthyl<smiles></smiles>

24 examples (75-92\%)

$\mathrm{Ar}=$ phenyl, 2-furanyl, 2-thiophenyl $\mathrm{R}_{1}=\mathrm{H}, \mathrm{Me}$

Scheme 29. Synthesis of complex heterocyclic compounds using DES as unconventional solvent and catalyst. 


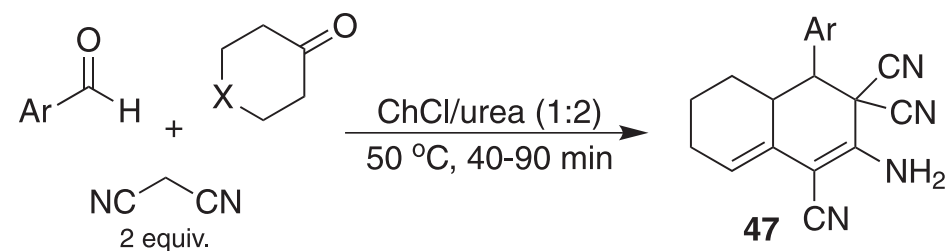

15 examples (64-95\%)

$\mathrm{Ar}=$ phenyl, substituted

phenyl, 2-furanyl, 2-thiophenyl

$\mathrm{X}=\mathrm{CH}_{2}, \mathrm{O}$

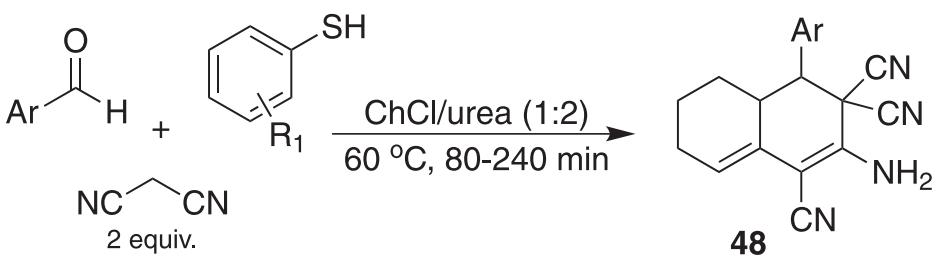

20 examples (60-82\%)

$\mathrm{Ar}=$ phenyl, substituted phenyl,

2-furanyl, 2-thiophenyl, 4-pyridinyl

$\mathrm{R}_{1}=\mathrm{H}, 4-\mathrm{Me}$

Scheme 30. ChCl/urea-mediated synthesis of cyclohexa-1,3-dienamines (47) and pyridines (48).

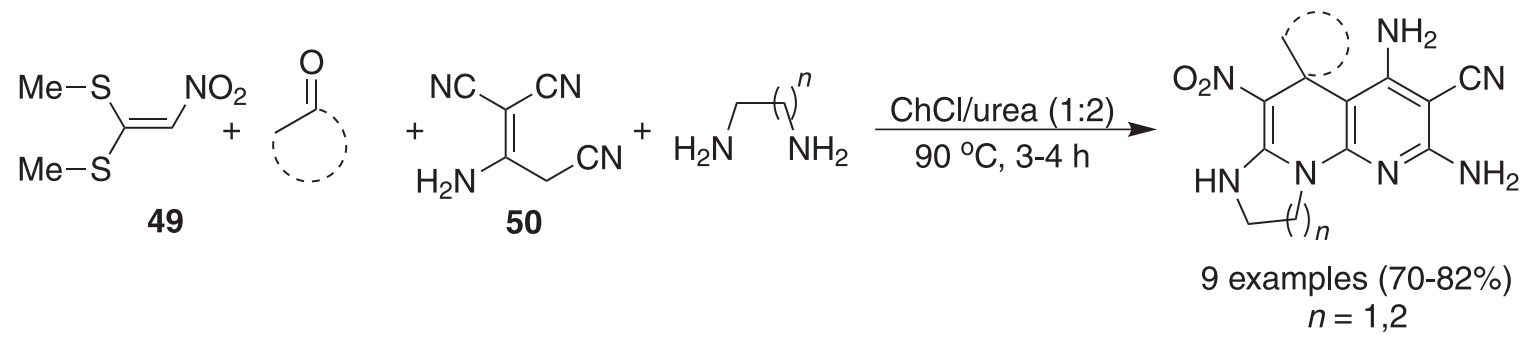

carbonyl compounds<smiles>[X]c1ccc(C=O)cc1</smiles>

$\mathrm{X}=4-\mathrm{Br}, 2,4-\mathrm{diCl}, 4-\mathrm{NO}_{2}, 3-\mathrm{NO}_{2}$<smiles>O=Cc1ccc2ccccc2c1</smiles>

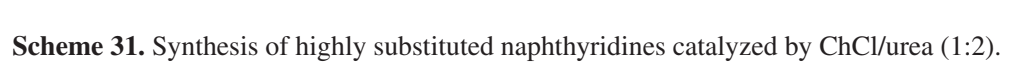

1920s, who studied the reaction of carboxylic acids, carbonyl compounds and isocyanides to prepare $\alpha$-acyloxyamides. Later, $\mathrm{Ugi}^{41}$ added a fourth component to the mixture, an amine, and the reaction, which was named after your contribution, is so far used to produce unnatural dipeptides with high degree of molecular diversity. Excellent review contributions on Passerini and Ugi multicomponent reactions can be found elsewhere. ${ }^{51,140-142}$

The first example of IMCR carried out in deep eutectic mixtures was reported by Azizi et al. ${ }^{143}$ in 2013. The authors studied the Ugi reaction in $\mathrm{ChCl} /$ urea (1:2) as solvent to produce a series of dipeptides $\mathbf{5 5}$ in good to excellent yields (Scheme 33). The deep eutectic solvent could be recycled and reused in four consecutive cycles without significant loss of activity.

More recently, Singh et al. ${ }^{144}$ described an interesting pseudo-four component Ugi/oxidation approach using IBX (2-iodoxybenzoic acid) in $\mathrm{ChCl} /$ urea as eutectic solvent. Upon addition of 1.0 equivalent of IBX to the reaction mixture, the straightforward oxidation of the benzylamines led to the in situ formation of aldehydes, which in turn react with a second equivalent of the amine to form the corresponding imine as intermediate. Further reaction of this intermediate with the carboxylic acid and isocyanide furnished the desired dipeptides in good to excellent yields (Scheme 34). The authors mentioned that the oxidant IBX 


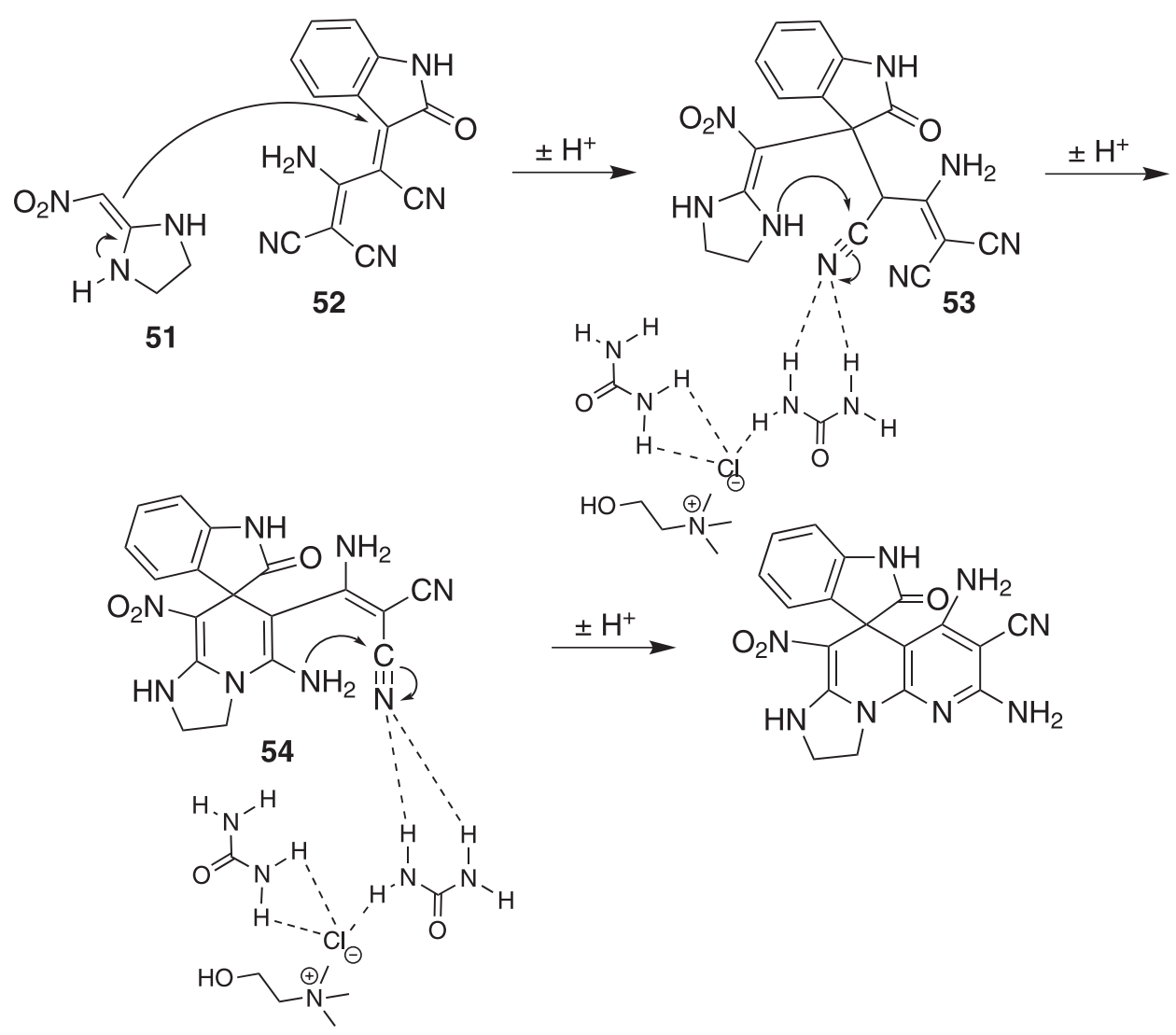

Scheme 32. Proposed mechanism for $\mathrm{ChCl} /$ urea-catalyzed synthesis of naphthyridines.<smiles>[R][R]1cccc(C(C(=O)NC2CCCCC2)N(C(=O)c2ccccc2)c2cccc([R])c2)c1</smiles>

18 examples $(60-92 \%)$

$\mathrm{R}_{1}=\mathrm{H}$, 4-OMe, 4-Me, 2-Me, 4-Cl, 4-Br, 3,4-diCl

$\mathrm{R}_{2}=\mathrm{H}, 4-\mathrm{OMe}, 3-\mathrm{OMe}, 4-\mathrm{Cl}, 2-\mathrm{Cl}, 4-\mathrm{NO}_{2}, 2,4-\mathrm{diCl}$

Scheme 33. Ugi multicomponent reaction in $\mathrm{ChCl} /$ urea (1:2) as DES.

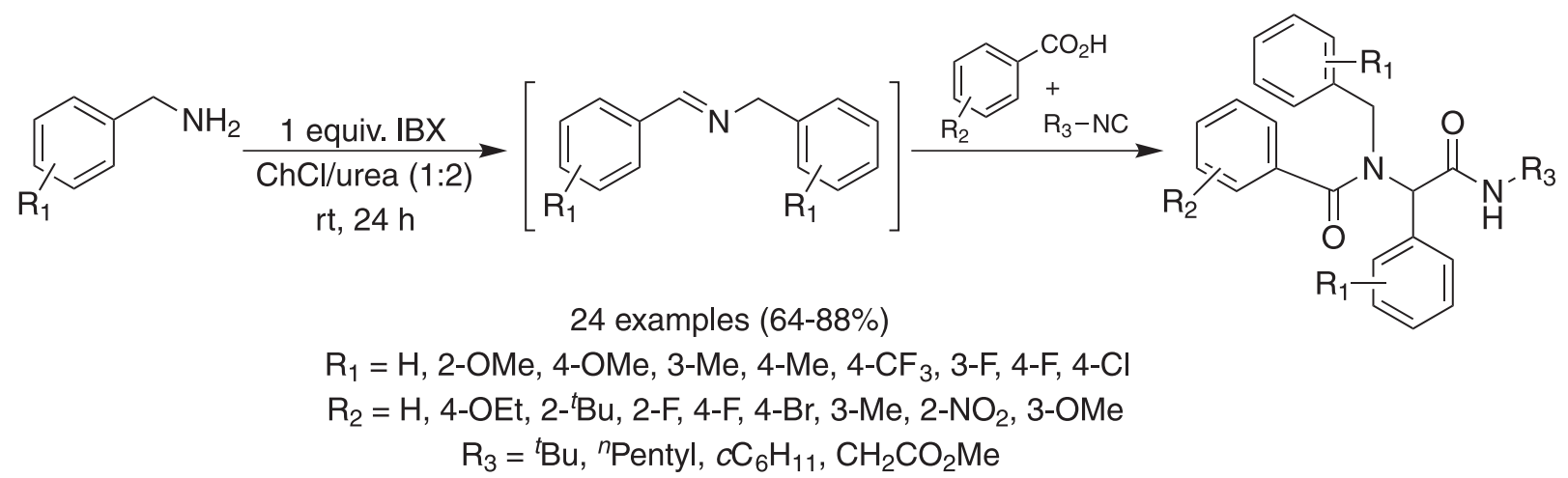


(re-oxidized by Oxone ${ }^{\circledR}$ ) and the $\mathrm{ChCl} /$ urea mixture could be recycled and reused for up to five cycles with only a slight loss in activity.

Passerini reaction was also investigated in deep eutectic solvents. In 2016, Shaabani et al. ${ }^{145}$ described the first attempt to perform Passerini reaction in $\mathrm{ChCl} /$ urea (1:2) as solvent. The reaction of a series of aliphatic and aromatic aldehydes and carboxylic acids with cyclohexyl isocyanide or tert-butyl isocyanide in $\mathrm{ChCl} /$ urea $(1: 2)$ at $60{ }^{\circ} \mathrm{C}$ led to the corresponding $\alpha$-acyloxy- $N$-alkylamides in $65-94 \%$ yield (Scheme 35).

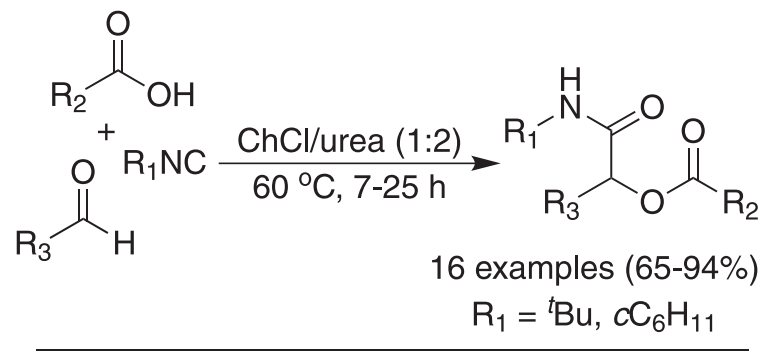<smiles>[X]c1ccc(C(=O)OCCCCC(=O)O)cc1</smiles>

aldehydes $\left(R_{3}\right)$

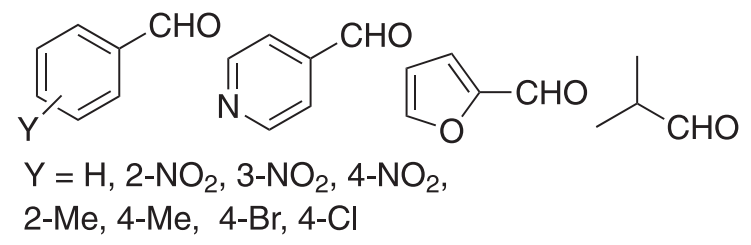

Scheme 35. Passerini multicomponent reactions in $\mathrm{ChCl} / \mathrm{urea}(1: 2)$ as green solvent.

In 1998, a new isocyanide-based MCR was simultaneously described by three different and independent research groups. ${ }^{42}$ The reaction takes place between aminoazoles, aldehydes and isocyanides to form annulated nitrogen-containing products, depending on the aminoazole used as starting material. ${ }^{48,49}$ The so-called Groebke-Blackburn-Bienaymé (GBB) reaction rapidly became a very popular tool to prepare nitrogen heterocycles, specially imidazo[1,2-a]pyridines (when 2-aminopyridine is used as reagent), ${ }^{146,147}$ This is a convenient scaffold for the synthesis of biologically active compounds such as the anxiolytic drug Alpidem or the hypnotic drug Zolpidem.

Two different approaches to perform GBB reaction in DES were independently described by two Iranian research groups in 2016. Firstly, Shaabani and Hooshmand ${ }^{148}$ reported the use of $\mathrm{ChCl} /$ urea (1:2) as solvent and organocatalyst for the preparation of a series of different nitrogen heterocycles (Scheme 36; selected examples for imidazo[1,2-a] pyridines $\left(\mathrm{X}=\mathrm{CH}_{2}\right)$ and imidazo[1,2-a]pyrazines, $\left.\mathrm{X}=\mathrm{N}\right)$. The reaction of different 2-aminoheterocycles, aromatic aldehydes and alkyl isocyanides furnished the desired 3-aminoimidazo-fused heterocycles in good to excellent yields under mild conditions. According to the authors, the DES could be recovered after the reaction and reused up to four new cycles without loss of activity.
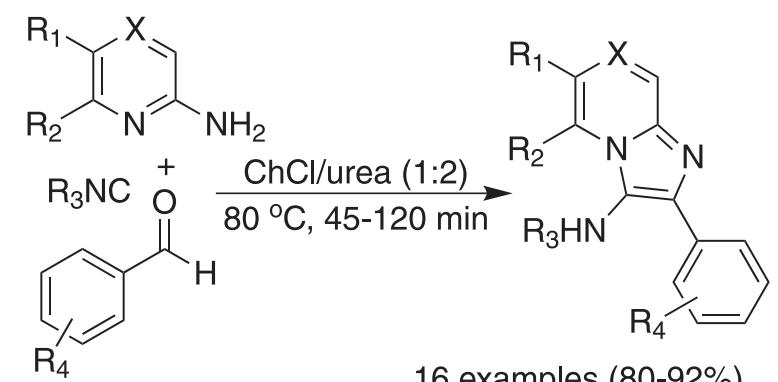

16 examples $(80-92 \%)$

$$
\begin{gathered}
\mathrm{X}=\mathrm{CH}, \mathrm{N} \\
\mathrm{R}_{1}=\mathrm{H}, \mathrm{Br} \\
\mathrm{R}_{2}=\mathrm{H}, \mathrm{Me} \\
\mathrm{R}_{3}={ }^{t} \mathrm{Bu}, \mathrm{CC}_{6} \mathrm{H}_{11} \\
\mathrm{R}_{4}=\mathrm{H}, 4-\mathrm{NO}_{2}, 3-\mathrm{NO}_{2}, 4-\mathrm{F}, \\
4-\mathrm{Br}, 4-\mathrm{Cl}, 4-\mathrm{Me}, 4-\mathrm{OMe},
\end{gathered}
$$

Scheme 36. Groebke-Blackburn-Bienaymé reaction catalyzed by $\mathrm{ChCl} /$ urea (1:2).

Later that same year, Azizi and Dezfooli ${ }^{149}$ also described the use of $\mathrm{ChCl} /$ urea (1:2) as solvent for the synthesis of imidazo[1,2-a]pyridines derived exclusively from 2-aminopyridines via Groebke-Blackburn-Bienaymé reaction.

\subsection{Miscellaneous}

Imidazo[1,2-a]pyridines can also be prepared by the copper-catalyzed multicomponent reaction of 2-aminopyridines, aldehydes and terminal alkynes. In 2014, $\mathrm{Lu}$ et al. ${ }^{150}$ firstly screened different deep eutectic mixtures for this MCR catalyzed by superparamagnetic $\mathrm{CuFeO}_{2}$ nanoparticles. Thus, the desired nitrogen-based heterocycles $\mathbf{5 6}$ could be obtained in excellent yields (80-95\%), when the three components of the reaction were heated in citric acid/ DMU (2:3) at $65{ }^{\circ} \mathrm{C}$ for 6-14 h (Scheme 37).

Dithiocarbamates are a class of natural and synthetic thiocompounds with biologically important properties such as fungicide and anticancer agents. ${ }^{151-156}$ Azizi and Gholibeglo ${ }^{157}$ have studied the use of DES as green media for the one-pot multicomponent reaction to prepare this class of compounds. For example, the reaction of carbon disulfide $\left(\mathrm{CS}_{2}\right)$, primary or secondary amines, and epoxides 


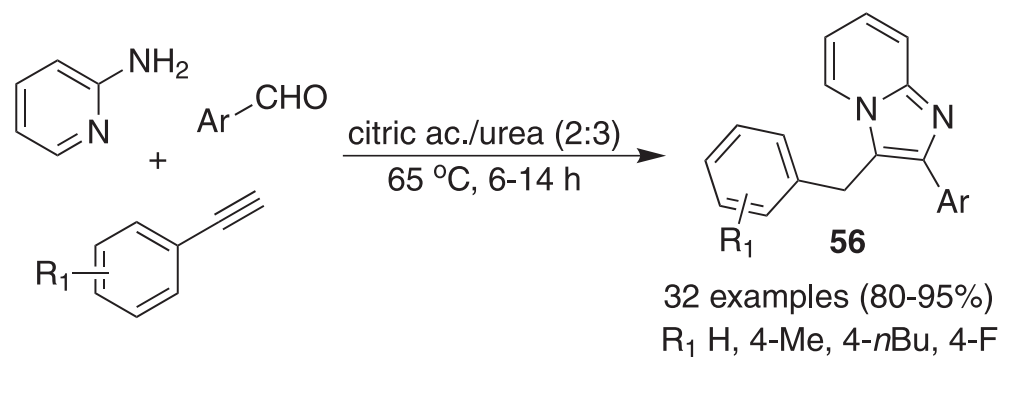

$$
\begin{aligned}
& \text { aldehydes (Ar) } \\
& 4-\mathrm{CF}_{3}, 3-\mathrm{OMe}, 3-\mathrm{OPh}, 3-\mathrm{Cl}, 3-\mathrm{CF}_{3}, 2-\mathrm{Cl}
\end{aligned}
$$

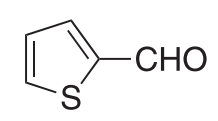

Scheme 37. $\mathrm{CuFeO}_{2}$ NP-catalyzed MCR to prepare imidazo[1,2-a]pyridines (56) using citric acid/DMU (2:3) as DES.

in $\mathrm{ChCl} /$ urea (1:2) mixture at room temperature furnished the corresponding 2-hydroxydithiocarbamates (57) in good to excellent yields (Scheme 38). Later, the same group ${ }^{158}$ described a similar approach for the synthesis of amino acid-derived dithiocarbamates, also using $\mathrm{ChCl} /$ urea (1:2) mixture as green solvent.<smiles>[R6]N[R5](=O)C1CO1</smiles>

$$
\text { amines }\left(\mathrm{R}_{2} \mathrm{R}_{3}\right)
$$

Scheme 38. $\mathrm{ChCl} /$ urea-mediated synthesis of dithiocarbamates (57).

The ring opening of epoxides by $S$-alkyl isothiouronium salts was also described by the same group. ${ }^{159}$ In this straightforward and odorless approach, the nucleophile was generated in situ through the base-catalyzed reaction of thiourea with alkyl halides in choline chloride/urea eutectic mixtures as green solvent and catalyst. Further reaction with different epoxides led to the $\beta$-hydroxy sulfides (58) in good to excellent yields (Scheme 39).

The postulated mechanism involves a nucleophilic attack of the thiourea to the alkyl halide furnishing the corresponding $S$-alkyl isothiouronium salt as intermediate 59. According to the authors, this step would be accelerated

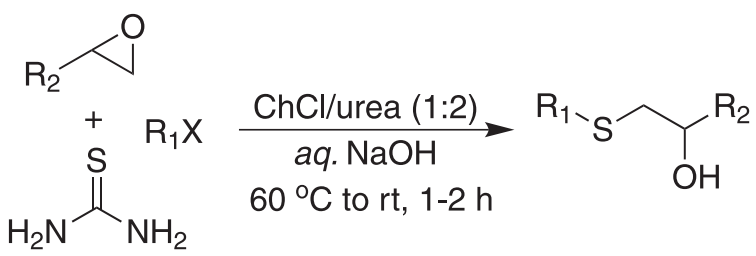

$$
\begin{gathered}
18 \text { examples }(70-95 \%) \\
X=\mathrm{Cl}, \mathrm{Br}, \mathrm{I} \\
\mathrm{R}_{1}=\mathrm{Bn}, \mathrm{Me}, \mathrm{Bu}, \mathrm{CH}_{2} \mathrm{CH}=\mathrm{CH}_{2} \\
\mathrm{R}_{2}=\mathrm{Et}, \mathrm{Ph} \mathrm{CH}_{2} \mathrm{OPh}, \mathrm{CH}_{2} \mathrm{O}^{\prime} \mathrm{Pr}, \mathrm{CH}_{2} \mathrm{OCH}_{2} \mathrm{CH}=\mathrm{CH}_{2}
\end{gathered}
$$

Scheme 39. Synthesis of $\beta$-hydroxy sulfides (58) in $\mathrm{ChCl} /$ urea (1:2).

due to the ionic nature of the DES. The hydrolysis of $\mathbf{5 9}$ with $\mathrm{NaOH}$, followed by a thiolate nucleophilic attack to the epoxide, under choline chloride/urea mediated catalysis, gives the desired product (Scheme 40). ${ }^{159}$

Eutectic mixtures can also catalyze the synthesis of 5-arylidene-2-imino-4-thiazolidones (60). Mobinikhaledi and Amiri ${ }^{160}$ described the multicomponent reaction of $\mathrm{N}, \mathrm{N}$-disubstituted thioureas, chloroacetyl chloride and aromatic aldehydes in choline chloride/urea (1:2) as green solvent/catalyst (Scheme 41). It is worthy to mention that the Z-configuration of the exocyclic double bonds was determined by proton nuclear magnetic resonance and comparison with analogous 4-thiazolidones.

Recently, Shahcheragh et al. ${ }^{161}$ described the use of choline chloride-based eutectic mixtures in the synthesis of 1,3,4-thiadiazoles compounds. The one-pot three component reaction between thiocarbohydrazide (61) and carbonyl compounds 62 (mainly aldehydes) and ketene $S, S$-acetals $(\mathbf{6 3 a}$ or $\mathbf{6 3 b})$ in $\mathrm{ChCl} /$ urea $(1: 2)$ at $80{ }^{\circ} \mathrm{C}$ led to the desired highly substituted thiadiazoles $(\mathbf{6 4 a}$ or $\mathbf{6 4 b})$ in moderate to good yields (Scheme 42). 


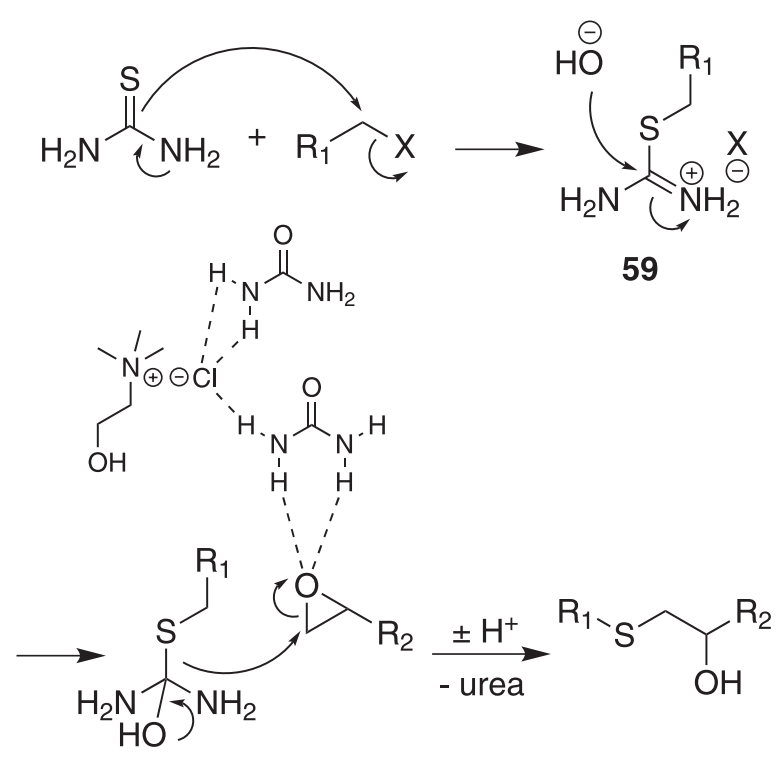

Scheme 40. Proposed mechanism for the multicomponent synthesis of $\beta$-hydroxy sulfides catalyzed by $\mathrm{ChCl} /$ urea (1:2).

Gewald multicomponent reaction is defined as the condensation of a carbonyl compound (aldehyde or ketone) with elemental sulfur and $\alpha$-cyanoesters (or derivatives) to prepare highly substituted 2-aminothiophenes. ${ }^{162}$ In 2017 , Shaabani et al. ${ }^{163}$ described the first example of Gewald reaction carried out in deep eutectic solvents. The reaction between malononitrile or ethyl $\alpha$-cyanoacetate, aldehydes or ketones, and $\mathrm{S}_{8}$, using $\mathrm{ChCl} /$ urea (1:2) as solvent and $\mathrm{NaOH}$ as base, led to several 2-aminothiophenes in moderate to good yields (Scheme 43).

\section{Conclusions and Perspectives}

Multicomponent reactions are acknowledged as powerful tools to synthesize a series of interesting organic compounds, especially heterocycles. The complete replacement of VOCs in these organic transformations is not a realistic task and more attention should be paid to the life cycle assessment of the solvents involved in all procedure steps, i.e., reaction, washings, purification, etc. ${ }^{11}$ The use of deep eutectic mixtures as solvent/catalyst in multicomponent reactions can be seen as an improvement, especially in the case of natural-based deep eutectic mixtures composed of components derived from renewable resources. The versatility of most of the DES studied to date arises from their good compatibility with several functional groups in the starting materials and products as well as with additives such as oxidants (IBX, Oxone ${ }^{\circledR}$ ), acids, bases, among others. In addition, multicomponent reactions can be performed in deep eutectic mixtures under relatively mild conditions. However, the majority of the studies published so far are incremental approaches focusing on the use of choline chloride/urea-based eutectic mixtures, with modest innovation in experimental procedures and solvent replacement. In many cases, a proposed mechanism of acid catalysis via hydrogen-bond activation or Lewis acid catalysis of carbonyl compounds to nucleophilic attack is postulated. No further investigations on the actual role of DES as catalyst is presented so far. In this scenario, we identify many opportunities for new investigation studies on the mechanistic effects of eutectic mixtures in multicomponent reactions, in order to provide new insights into the development of interesting and innovative approaches to the synthesis of even more complex organic compounds.

\section{Acknowledgments}

The authors gratefully acknowledge Fundação de Amparo à Pesquisa do Estado de São Paulo (FAPESP) for financial support (2007/07338-6; 2015/11155-0). Marcus V. Craveiro also acknowledges FAPESP for a postdoctoral fellowship (2016/22636-2).<smiles>[X]c1ccc(NC(=S)Nc2ccccc2[Y])cc1</smiles><smiles>[X]c1cccc(/C=C2\S/C(=N\c3ccccc3[Y])N(c3cccc([Y])c3)C2=O)c1</smiles>

17 examples $(70-94 \%)$

$\mathrm{X}=\mathrm{H}, \mathrm{Cl}, \mathrm{NO}_{2}, \mathrm{Me}, \mathrm{OMe}, \mathrm{OH}$

$\mathrm{Y}=\mathrm{H}, \mathrm{Cl}, \mathrm{Me}, \mathrm{Et}, \mathrm{Bu}$,

Scheme 41. The multicomponent synthesis of 5-arylidene-2-imino-4-thiazolidones (60). 
<smiles>[R16]C([R15])=O</smiles>

62<smiles>CC(C)=C1C(=O)NC(=O)NC1=O</smiles>
$63 b$ carbonyl component<smiles>[X]c1cccc(C=O)c1</smiles><smiles>O=Cc1[Y]ccc1</smiles>

$\mathrm{X}=\mathrm{OMe}, \mathrm{OH}, \mathrm{NO}_{2}, \mathrm{Cl}, \mathrm{NMe}_{2}$ $\mathrm{Y}=\mathrm{S}, \mathrm{O}$<smiles>CCC(Br)=NNC1=NNC(=C2C(=O)OC(C)(C)OC2=O)S1</smiles>

(H) $\mathrm{R}_{2}$<smiles>[R7]C([R7])=NNC1=NNC(=C2C(=O)NC(=O)NC2=O)S1</smiles>

$64 b$

$64 a$

24 examples (60-85\%)

Scheme 42. Synthesis of highly substituted 1,3,4-thiadiazoles in ChCl/urea (1:2).<smiles>[R7]CC#N</smiles>

13 examples (68-88\%)

$\mathrm{R}_{1}=\mathrm{CN}, \mathrm{CO}_{2} \mathrm{Et}$

$\mathrm{R}_{2}=\mathrm{Me}, \mathrm{Et},{ }^{n} \mathrm{Pr}$

\section{ketone component}

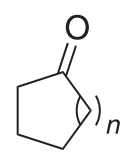<smiles>CC(C)=O</smiles><smiles>CCCC1CCC(=O)CC1</smiles>

$n=1,2,3,4$

Scheme 43. Gewald synthesis of 2-aminothiophenes in $\mathrm{ChCl} /$ urea (1:2).

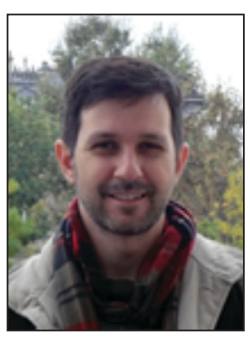

Luiz S. Longo Jr. received his BSc degree in Pharmacy in 1998 and his PhD degree in Organic Chemistry in 2003, both from the University of São Paulo, Brazil. In 2013, he joined the Ionic Liquid Group of The University of Nottingham (UoN) as a postdoctoral fellow under the supervision of Professor Peter Licence. Currently, he is a research collaborator of the GlaxoSmithKline Carbon Neutral Laboratories at UoN and Associate Professor of Organic and Medicinal Chemistry at the Federal University of São Paulo. His main research interests rely on the study of physical and chemical properties of ionic liquids and deep eutectic mixtures containing Lewis acids, using X-ray photoelectron spectroscopy, and their use as solvent/catalyst for multicomponent reactions applied to the synthesis of biologically active organic compounds (antimicrobial and antitumor).

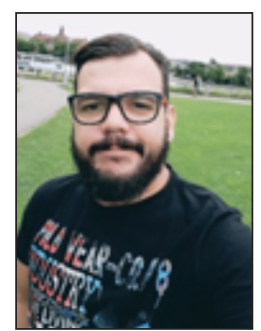

Marcus V. Craveiro is an Assistant Professor in Organic Chemistry at Federal University of São Paulo who teaches several courses. He has a bachelor's degree in Chemistry from the University of São Paulo (USP), Brazil, MSc and PhD degrees in Organic Chemistry also from USP. Currently, he is a post-doc fellow at University of Basel, Switzerland, working on C-Hsp3 activation. His research interests include natural products synthesis specially those containing indane skeleton. His main publications are related to indole alkaloid synthesis and indane molecules via ring-contraction reactions.

\section{References}

1. Varma, R. S.; ACS Sustainable Chem. Eng. 2016, 4, 5866.

2. Dunn, P. J.; Chem. Soc. Rev. 2012, 41, 1452. 
3. Sheldon, R. A.; Chem. Soc. Rev. 2012, 41, 1437.

4. Lenardão, E. J.; Freitag, R. A.; Dabdoub, M. J.; Batista, A. C. F.; Silveira, C. C.; Quim. Nova 2003, 26, 123.

5. Machado, A. A. S. C.; Quim. Nova 2012, 35, 1250.

6. Poliakoff, M.; Licence, P.; Nature 2007, 450, 810.

7. Constable, D. J. C.; Gonzales, C. J.; Henderson, R. K.; Org. Process Res. Dev. 2007, 11, 133.

8. Afonsi, K.; Colberg, J.; Dunn, P. J.; Fevig, T.; Jennings, S.; Johnson, T. A.; Kleine, H. P.; Knight, C.; Nagy, M. A.; Perry, D. A.; Stefaniak, M.; Green Chem. 2008, 10, 31.

9. Henderson, R. K.; Gonzales, C. J.; Constable, D. J. C.; Alston, S. R.; Inglis, G. G. A.; Fisher, G.; Sherwood, J.; Binks, S. P.; Curzons, A. D.; Green Chem. 2011, 13, 854.

10. Prat, D.; Pardigon, O.; Flemming, H.-W.; Letestu, S.; Ducandas, V.; Isnard, P.; Guntrum, E.; Senac, T.; Ruisseau, S.; Cruciani, P.; Hosek, P.; Org. Process Res. Dev. 2013, 17, 1517.

11. Clark, J. H.; Tavener, W. J.; Org. Process Res. Dev. 2007, 11, 149.

12. Wilkes, J. S.; Wasserscheid, P.; Welton, T.; Ionic Liquids in Synthesis, $2^{\text {nd }}$ ed.; Wiley-VCH Verlag GmbH \& Co. KGaA: Weinheim, Germany, 2008.

13. Deetlefs, M.; Seddon, K. R.; Green Chem. 2010, 12, 17.

14. Ranke, J.; Stolte, S.; Stormann, R.; Arning, J.; Jastorff, B.; Chem. Rev. 2007, 107, 2183.

15. Abbott, A. P.; Capper, G.; Davies, D. L.; Rasheed, R. K.; Tambyrajah, V.; Chem. Commun. 2003, 9, 70.

16. Francisco, M.; van den Bruinhorst, A.; Kroon, M. C.; Angew. Chem., Int. Ed. 2013, 52, 3074.

17. Avalos, M.; Babiano, R.; Cintas, P.; Jiménez, J. L.; Palacios, J. C.; Angew. Chem., Int. Ed. 2006, 45, 3904.

18. Tang, B.; Row, K. H.; Monatsh. Chem. 2013, 144, 1427.

19. Paiva, A.; Craveiro, R.; Aroso, I.; Martins, M.; Reis, R. L.; Duarte, A. R. C.; ACS Sustainable Chem. Eng. 2014, 2, 1063.

20. Liu, P.; Hao, J. W.; Mo, L. P.; Zhang, Z. H.; RSC Adv. 2015, 5, 48675.

21. Alonso, D. A.; Baeza, A.; Chinchilla, R.; Guillena, G.; Pastor, I. M.; Ramón, D. J.; Eur. J. Org. Chem. 2016, 2016, 612.

22. Khandelwal, S.; Tailor, Y. K.; Kumar, M.; J. Mol. Liq. 2016 215,345 .

23. García-Álvarez, J.; Eur. J. Inorg. Chem. 2015, 2015, 5147.

24. Durand, E.; Lecomte, J.; Villeneuve, P.; Eur. J. Lipid Sci. Technol. 2013, 115, 379.

25. Guajardo, N.; Muller, C. R.; Schrebler, R.; Carlesi, C.; María, P. D.; ChemCatChem 2016, 8, 1020.

26. del Monte, F.; Carriazo, D.; Serrano, M. C.; Guitiérrez, M. C.; Ferrer, M. L.; ChemSusChem 2014, 7, 999.

27. Chakrabarti, M. H.; Mjalli, F. S.; AlNashef, I. M.; Hashim, M. A.; Hussain, M. A.; Bahadori, L.; Low, C. T. J.; Renewable Sustainable Energy Rev. 2014, 30, 254.

28. Abo-Hamad, A.; Hayyan, M.; AlSaadi, M. A.; Hashim, M. A.; Chem. Eng. J. 2015, 273, 551 .
29. Vigier, K. O.; Chatel, G.; Jérôme, F.; ChemCatChem 2015, 7, 1250.

30. Zhao, H.; Baker, G. A.; J. Chem. Technol. Biotechnol. 2013, $88,3$.

31. Pena-Pereira, F.; Namiesnik, J.; ChemSusChem 2014, 7, 1784.

32. Tang, B.; Zhang, H.; Row, K. H.; J. Sep. Sci. 2015, 38, 1053.

33. García, G.; Aparicio, S.; Ullah, R.; Atilhan, M.; Energy Fuels 2015, 29, 2616.

34. Zhang, Q.; Vigier, K. O.; Royer, S.; Jérôme, F.; Chem. Soc. Rev. 2012, 41, 7108 .

35. Smith, E. L.; Abbott, A. P.; Ryder, K. S.; Chem. Rev. 2014, 114, 11060.

36. Zhu, J.; Bienaymé, H.; Multicomponent Reactions; Wiley-VCH Verlag GmbH \& Co. KGaA: Weinheim, Germany, 2005.

37. Strecker, A.; Ann. Chem. Pharm. 1850, 75, 27.

38. Strecker, A.; Ann. Chem. Pharm. 1854, 91, 349.

39. Passerini, M. S. L.; Gazz. Chim. Ital. 1921, 51, 126.

40. Ugi, I.; Angew. Chem. 1962, 74, 9.

41. Ugi, I.; Steinbrückner, C.; Angew. Chem. 1960, 72, 267.

42. Groebke, K.; Weber, L.; Mehlin, F.; Synlett 1998, 661; Bienaymé, H.; Bouzid, K.; Angew. Chem., Int. Ed. 1998, 37, 2234; Blackburn, C.; Tetrahedron Lett. 1998, 39, 469.

43. Mannich, C.; Krösche, W.; Arch. Pharm. 1912, $250,647$.

44. Biginelli, P.; Ber. Dtsch. Chem. Ges. 1891, 24, 2962.

45. Hantzsch, A.; Justus Liebigs Ann. Chem. 1882, 215, 1.

46. Dömling, A.; Wang, W.; Wang, K.; Chem. Rev. 2012, 112, 3083.

47. Váradi, A.; Palmer, T. C.; Dardashti, R. N.; Majumdar, S.; Molecules 2016, 21, 19.

48. Shaaban, S.; Abdel-Wahab, B. F.; Mol. Diversity 2016, 20, 233.

49. Devi, N.; Rawal, R. K.; Singh, V.; Tetrahedron 2015, 71, 183.

50. Cioc, R. C.; Ruijter, E.; Orru, R. V. A.; Green Chem. 2014, 16, 2958.

51. Liu, Z. Q.; Curr. Org. Chem. 2014, 18, 719.

52. de Graaff, C.; Ruijter, E.; Orru, R. V.; Chem. Soc. Rev. 2012, $41,3969$.

53. Van Berkel, S. S.; Bögels, B. G. M.; Wijdeven, M. A.; Westermann, B.; Rutjes, F. P. J. T.; Eur. J. Org. Chem. 2012, 3543.

54. Ruijter, E.; Scheffelaar, R.; Orru, R. V. A.; Angew. Chem., Int. Ed. 2011, 50, 6234.

55. Ramon, D. J.; Yus, M.; Angew. Chem., Int. Ed. 2005, 44, 1602.

56. Cao, J.; Shang, Y.; Qi, B.; Sun, X.; Zhang, L.; Liu, H.; Zhang, H.; Zhou, X.; RSC Adv. 2015, 5, 9993.

57. Abbott, A. P.; Barron, J. C.; Ryder, K. S.; Wilson, D.; Chem. Eur. J. 2007, 13, 6495.

58. Abbott, A. P.; Capper, G.; Davies, D. L.; Munro, H. L.; Rasheed, R. K.; Tambyrajah, V.; Chem. Commun. 2001, 2010.

59. Hsiu, S.-I.; Huang, J.-F.; Sun, I. W.; Yuan, C.-H.; Shiea, J.; Electrochim. Acta 2002, 47, 4367.

60. Lin, Y.-F.; Sun, I. W.; Electrochim. Acta 1999, 44, 2771. 
61. Abbott, A. P.; Capper, G.; Davies, D. L.; Rasheed, R.; Inorg. Chem. 2004, 43, 3447.

62. Hurley, F. H.; Wier, T. P.; J. Electrochem. Soc. 1951, 98, 207.

63. Sitze, M. S.; Schreiter, E. R.; Patterson, E. V.; Freeman, R. G.; Inorg. Chem. 2001, 40, 2298.

64. Xu, W.-G.; Lü, X.-M.; Zhang, Q.-G.; Gui, J.-S.; Yang, J.-Z.; Chin. J. Chem. 2006, 24, 331.

65. Yang, J.-Z.; Tian, P.; He, L.-L.; Xu, W.-G.; Fluid Phase Equilib. 2003, 204, 295.

66. Abbott, A. P.; Capper, G.; Davies, D. L.; Rasheed, R. K.; Chem. - Eur. J. 2004, 10, 3769.

67. Cao, J.; Qi, B.; Liu, J.; Shang, Y.; Liu, H.; Wang, W.; Lv, J.; Chen, Z.; Zhang, H.; Zhou, X.; RSC Adv. 2016, 6, 21612.

68. Francisco, M.; van den Bruinhorst, A.; Kroon, M. C.; Green Chem. 2012, 14, 2153.

69. Shao, X.; Wang, L.; Li, M.; Jia, D.; Thermochim. Acta 2012 , $547,70$.

70. Safarov, J.; Hamidova, R.; Zepik, S.; Schmidt, H.; Kul, I.; Shahverdiyev, A.; Hassel, E.; J. Mol. Liq. 2013, 187, 137.

71. Biginelli, P.; Ber. Dtsch. Chem. Ges. 1891, 24, 1317.

72. Gore, S.; Baskaran, S.; Koenig, B.; Green Chem. 2011, 13, 1009.

73. Azizi, N.; Dezfuli, S.; Hahsemi, M. M.; Sci. World J. 2012, 2012, 908702.

74. Noolvi, M. N.; Patel, H. M.; Bhardwaj, V.; Chauhan, A.; Eur. J. Med. Chem. 2011, 46, 2327.

75. El-Azab, A. S.;Al-Omar, M. A.; Abdel-Aziz, A. A.; Abdel-Aziz, N. I.; el-Sayed, M. A.; Aleisa, A. M.; Sayed-Ahmed, M. M.; Abdel-Hamide, S. G.; Eur. J. Med. Chem. 2010, 45, 4188.

76. Poudapally, S.; Battu, S.; Velatooru, L. R.; Bethu, M. S.; Janapala, V. R.; Sharma, S.; Sen, S.; Pottabathini, N.; Iska, V. B. R.; Katangoor, V.; Bioorg. Med. Chem. Lett. 2017, 27, 1923.

77. Kumar, A.; Sharma, P.; Kumari, P.; Lal Kalal, B.; Bioorg. Med. Chem. Lett. 2011, 21, 4353.

78. Mohamed, T.; Rao, P. P. N.; Eur. J. Med. Chem. 2017, 126, 823.

79. Balakumar, C.; Lamba, P.; Kishore, D. P.; Narayana, B. L.; Rao, K. V.; Rajwinder, K.; Rao, A. R.; Shireesha, B.; Narsaiah, B.; Eur. J. Med. Chem. 2010, 45, 4904.

80. Alafeefy, A. M.; Kadi, A. A.; Al-Deeb, O. A.; El-Tahir, K. E. H.; Al-Jaber, N. A.; Eur. J. Med. Chem. 2010, 45, 4947.

81. Held, F. E.; Guryev, A. A.; Frohlich, T.; Hampel, F.; Kahnt, A.; Hutterer, C.; Steingruber, M.; Bahsi, H.; Bojnicic-Kninski, C.; Mattes, D. S.; Foertsch, T. C.; Nesterov-Mueller, A.; Marschall, M.; Tsogoeva, S. B.; Nat. Commun. 2017, 8, 15071.

82. Zhang, Z.-H.; Zhang, X.-N.; Mo, L.-P.; Li, Y.-X.; Ma, F.-P.; Green Chem. 2012, 14, 1502.

83. Lobo, H. R.; Singh, B. S.; Shankarling, G. S.; Catal. Commun. 2012, 27, 179.

84. Disale, S. T.; Kale, S. R.; Kahandal, S. S.; Srinivasan, T. G.; Jayaram, R. V.; Tetrahedron Lett. 2012, 53, 2277.
85. Hekmatsshoar, R. M. F.; Rahnamafar, R.; J. Chem. Sci. 2013, $125,1009$.

86. Azizi, N.; Manochehri, Z.; Nahayi, A.; Torkashvand, S.; J. Mol. Liq. 2014, 196, 153.

87. Bakavoli, M.; Eshghi, H.; Rahimizadeh, M.; Housaindokht, M. R.; Mohammadi, A.; Monhemi, H.; Res. Chem. Intermed. 2015, 41, 3497.

88. Bafti, B.; Khabazzadeh, H.; J. Chem. Sci. 2014, 126, 881.

89. Mobinikhaledi, A.; Amiri, A. K.; Res. Chem. Intermed. 2015, $41,2063$.

90. Hu, H. C.; Liu, Y. H.; Li, B. L.; Cui, Z. S.; Zhang, Z. H.; RSC Adv. 2015, 5, 7720 .

91. Rokade, S. M.; Garande, A. M.; Ahmad, N. A. A.; Bhate, P. M.; RSC Adv. 2015, 5, 2281.

92. Keshavarzipour, F.; Tavakol, H.; Catal. Lett. 2015, 145, 1062.

93. Batista, V. F.; Pinto, D. C. G. A.; Silva, A. M. S.; ACS Sustainable Chem. Eng. 2016, 4, 4064.

94. Prajapati, S. M.; Patel, K. D.; Vekariya, R. H.; Panchal, S. N.; Patel, H. D.; RSC Adv. 2014, 4, 24463.

95. Shahabi, D.; Tavakol, H.; J. Mol. Liq. 2016, 220, 324.

96. Azizi, N.; Edrisi, M.; Microporous Mesoporous Mater. 2017, 240,130

97. Azizi, N.; Edrisi, M.; Res. Chem. Intermed. 2017, 43, 379.

98. Azizi, N.; Dezfooli, S.; Khajeh, M.; Hashemi, M. M.; J. Mol. Liq. 2013, 186, 76.

99. Pednekar, S.; Bhalerao, R.; Ghade, N.; J. Chem. Sci. 2013, 125, 615.

100. Chaskar, A.; Lett. Org. Chem. 2014, 11, 480.

101. Azizi, N.; Dezfooli, S.; Hashemi, M. M.; C. R. Chim. 2013, 16, 997.

102. Navarro, C. A.; Sierra, C. A.; Ochoa-Puentes, C.; RSC Adv. 2016, 6, 65355.

103. Simeonov, S. P.; Afonso, C. A. M.; RSC Adv. 2016, 6, 5485.

104. Ye, N.; Chen, H.; Wold, E. A.; Shi, P. Y.; Zhou, J.; ACS Infect. Dis. 2016, 2, 382.

105. Kumari, G.; Nutan; Modi, M.; Gupta, S. K.; Singh, R. K.; Eur. J. Med. Chem. 2011, 46, 1181.

106. Ding, K.; Lu, Y.; Nikolovska-Coleska, Z.; Qiu, S.; Ding, Y.; Gao, W.; Stuckey, J.; Krajewski, K.; Roller, P. P.; Tomita, Y.; Parrish, D. A.; Deschamps, J. R.; Wang, S.; J. Am. Chem. Soc. 2005, 127, 10130.

107. Vintonyak, V. V.; Warburg, K.; Kruse, H.; Grimme, S.; Hubel, K.; Rauh, D.; Waldmann, H.; Angew. Chem., Int. Ed. 2010, 49, 5902.

108. Yeung, B. K.; Zou, B.; Rottmann, M.; Lakshminarayana, S. B.; Ang, S. H.; Leong, S. Y.; Tan, J.; Wong, J.; Keller-Maerki, S.; Fischli, C.; Goh, A.; Schmitt, E. K.; Krastel, P.; Francotte, E.; Kuhen, K.; Plouffe, D.; Henson, K.; Wagner, T.; Winzeler, E. A.; Petersen, F.; Brun, R.; Dartois, V.; Dagana, T. T.; Keller, T. H.; J. Med. Chem. 2010, 53, 5155. 
109. Pourshab, M.; Asghari, S.; Mohseni, M.; J. Heterocycl. Chem. 2018, 55, 173.

110. Bhaskar, G.; Arun, Y.; Balachandran, C.; Saikumar, C.; Perumal, P. T.; Eur. J. Med. Chem. 2012, 51, 79.

111. Tiwari, S.; Pathak, P.; Sagar, R.; Bioorg. Med. Chem. Lett. 2016, 26, 2513.

112. Fensome, A.; Adams, W. R.; Adams, A. L.; Berrodin, T. J.; Cohen, J.; Huselton, C.; Illenberger, A.; Kern, J. C.; Hudak, V. A.; Marella, M. A.; Melenski, E. G.; McComas, C. C.; Mugford, C. A.; Slayden, O. D.; Yudt, M.; Zhang, Z.; Zhang, P.; Zhu, Y.; Winneker, R. C.; Wrobel, J. E.; J. Med. Chem. 2008, 51, 1861.

113. Azizi, N.; Dezfooli, S.; Hashemi, M. M.; J. Mol. Liq. 2014, 194, 62.

114. Rajawat, A.; Khandelwal, S.; Kumar, M.; RSC Adv. 2014, 4, 5105.

115. Swaroop, T. R.; Sharath Kumar, K. S.; Palanivelu, M.; Chaitanya, S.; Rangappa, K. S.; J. Heterocycl. Chem. 2014, 51, 1866.

116. Bhosle, M. R.; Khillare, L. D.; Dhumal, S. T.; Mane, R. A.; Chin. Chem. Lett. 2016, 27, 370.

117. Zonouz, A. M.; Moghani, D.; Synth. Commun. 2016, 46, 220.

118. Azizi, N.; Mahboobe, M.; Edrisi, M.; Dyes Pigm. 2014, 100, 215.

119. Krishnammagari, S. K.; Cho, B. G.; Jeong, Y. T.; Phosphorus, Sulfur Silicon Relat. Elem. 2018, 193, 306.

120. Siddalingamurthy, E.; Mahadevan, K. M.; Kumar, T. O. S.; Synth. Commun. 2013, 43, 3153.

121. Cooper, L. C.; Chicchi, G. G.; Dinnell, K.; Elliott, J. M.; Hollingworth, G. J.; Kurtz, M. M.; Locker, K. L.; Morrison, D.; Shaw, D. E.; Tsao, K.-L.; Watt, A. P.; Williams, A. R.; Swain, C. J.; Bioorg. Med. Chem. Lett. 2001, 11, 1233.

122. Thompson, A. M.; Fry, D. W.; Kraker, A. K.; Denny, W. A.; J. Med. Chem. 1994, 37, 598.

123. Giraud, F.; Marchand, P.; Carbonnelle, D.; Sartor, M.; Lang, F.; Duflos, M.; Bioorg. Med. Chem. Lett. 2010, 20, 5203.

124. Jacobs, R. T.; Brown, F. J.; Cronk, L. A.; Aharony, D.; Buckner, C. K.; Kusner, E. J.; Kirkland, K. M.; Neilson, K. L.; J. Med. Chem. 1993, 36, 394.

125. Duflos, M.; Nourrsson, M.-R.; Brelet, J.; Courant, J.; LeBaut, B.; Grimaud, N.; Petit, J.-Y.; Eur. J. Med. Chem. 2001, 36, 545.

126. Aryan, R.; Beyzaei, H.; Nojavan, M.; Rezaei, M.; Res. Chem. Intermed. 2017, 43, 4731.

127. Kamble, S. S.; Shankarling, G. S.; ChemistrySelect 2018, 3, 2032.

128. Ma, C.-T.; Liu, P.; Wu, W.; Zhang, Z.-H.; J. Mol. Liq. 2017, $242,606$.

129. Roknabadi, M. H.; Mosslemin, M. H.; Mohebat, R.; J. Chem. Res. 2017, 41, 430.

130. Mahire, V. N.; Patel, V. E.; Mahulikar, P. P.; Res. Chem. Intermed. 2017, 43, 1847.
131. Tipale, M. R.; Khillare, L. D.; Deshmukh, A. R.; Bhosle, M. R.; J. Heterocycl. Chem. 2018, 55, 716.

132. Azizi, N.; Ahooie, T. S.; Hashemi, M. M.; J. Mol. Liq. 2017, $246,221$.

133. Azizi, N.; Haghayegh, M. S.; ChemistrySelect 2017, 2, 8870.

134. Shaabani, A.; Hooshmand, S. E.; Tabatabaei, A. T.; Tetrahedron Lett. 2016, 57, 351.

135. Dömling, A.; Ugi, I.; Angew. Chem., Int. Ed. 2000, 39, 3169.

136. Dömling, A.; Curr. Opin. Chem. Biol. 2002, 6, 306.

137. Dömling, A.; Chem. Rev. 2006, 106, 17.

138. Heravi, M. M.; Moghimi, S.; J. Iran. Chem. Soc. 2011, 8, 306.

139. Lygin, A. V.; de Meijere, A.; Angew. Chem., Int. Ed. 2010, 49, 9094.

140. El Kaïm, L.; Grimaud, L.; Eur. J. Org. Chem. 2014, 2014, 7749.

141. Kazemizadeh, A. R.; Ramazani, A.; Curr. Org. Chem. 2012, 16, 418.

142. El Kaïm, L.; Grimaud, L.; Mol. Diversity 2010, 14, 855.

143. Azizi, N.; Dezfooli, S.; Hashemi, M. M.; C. R. Chim. 2013, 16, 1098.

144. Singh, K.; Kaur, A.; Mithu, V. S.; Sharma, S.; J. Org. Chem. 2017, 82, 5285.

145. Shaabani, A.; Afshari, R.; Hooshmand, S. E.; Res. Chem. Intermed. 2016, 42, 5607.

146. Pericherla, K.; Kaswan, P.; Pandey, K.; Kumar, A.; Synthesis 2015, 47, 887.

147. Goel, R.; Luxami, V.; Paul, K.; RSC Adv. 2015, 5, 81608.

148. Shaabani, A.; Hooshmand, S. E.; Tetrahedron Lett. 2016, 57, 310.

149. Azizi, N.; Dezfooli, S.; Environ. Chem. Lett. 2016, 14, 201.

150. Lu, J.; Li, X.-T.; Ma, E. Q.; Mo, L.-P.; Zhang, Z.-H.; ChemCatChem 2014, 6, 2854.

151. Zhang, Y.; Talalay, P.; Cancer Res. 1994, 54, 1976 s.

152. Conaway, C. C.; Yang, Y.; Chung, F.; Curr. Drug Metab. 2002, 3, 233.

153. Cao, S.-L.; Feng, Y.-P.; Jiang, Y.-Y.; Liu, S.-Y.; Ding, G.-Y.; Li, R.-T.; Bioorg. Med. Chem. Lett. 2005, 15, 1915.

154. Hou, X.; Ge, Z.; Wang, T.; Guo, W.; Cui, J.; Cheng, T.; Lai, C.; Li, R.; Bioorg. Med. Chem. Lett. 2006, 16, 4214.

155. Ronconi, L.; Marzano, C.; Zanello, P.; Corsini, M.; Miolo, G.; Maccà, C.; Trevisan, A.; Fregona, D.; J. Med. Chem. 2006, 49, 1648.

156. Walter, W.; Bode, K.-D.; Angew. Chem., Int. Ed. Engl. 1967, $6,281$.

157. Azizi, N.; Gholibeglo, E.; RSC Adv. 2012, 2, 7413.

158. Azizi, N.; Marimi, M.; Environ. Chem. Lett. 2013, 11, 371.

159. Azizi, N.; Yadollahy, Z.; Rahimzadeh-Oskooee, A.; Synlett 2014, 25, 1085.

160. Mobinikhaledi, A.; Amiri, A. K.; Res. Chem. Intermed. 2013, 39, 1491.

161. Shahcheragh, S. M.; Habibi, A.; Khosravi, S.; Tetrahedron Lett. 2017, 58,855 . 
162. Gewald, K.; Schinke, E.; Bottcher, H.; Eur. J. Inorg. Chem. 1966, 99, 94.

163. Shaabani, A.; Hooshmand, S. E.; Afaridoun, H.; Monatsh. Chem. 2017, 148, 711.

Submitted: May 16, 2018

Published online: August 2, 2018 